\title{
Ceramics among Eurasian hunter-gatherers: 32000 years of ceramic technology use and the perception of containment
}

\author{
Mihael Budja \\ Department of Archaeology, Faculty of Arts, University of Ljubljana, SI \\ Mihael.Budja@ff.uni-lj.si
}

\begin{abstract}
We present two parallel and 32000 years long trajectories of episodic ceramic technology use in Eurasian pre-Neolithic hunter-gatherer societies. In eastern, Asian trajectory the pottery was produced from the beginning. Ceramic figurines mark the western, European trajectory. The western predates the eastern for about eleven millennia. While ceramic cones and figurines first appeared in Central Europe at c. 31000 cal BC the earliest vessels in eastern Asia was dated at c. 20000 cal BC. We discuss women's agency, perception of containment, 'cross-craft interactions', and evolution of private property that that may influenced the inventions of ceramic (pyro)technology.

IZVLEČEK - Predstavljamo dve vzporedni, 32000 let dolgi trajektoriji občasne uporabe keramične tehnologije pri evrazijskih pred-neolitskih skupnostih lovcev in nabiralcev. V vzhodni, azijski trajektoriji, so keramične posode izdelovali že od začetka. V zahodni, evropski, so najprej izdelovali keramične figurice in stožce. Začetek uporabe keramične tehnologije v Evropi je 11000 let starejši od začetka v jugovzhodni Aziji. Prvi keramični stožci in figurice so se v srednji Evropi pojavile pred 31000 leti pr.n.št. Prve keramične posode pa so v jugovzhodni Aziji začeli uporabljati pred 20000 leti pr.n.št. Analiziramo vlogo žensk, pomen shranjevanja in zasebne lastnine ter prenosa znanj in veščin pri razvoju keramične tehnologije.
\end{abstract}

KEY WORDS - hunter-gatherers; ceramic technology; invention; containment; radiocarbon dating

\section{Introduction}

When he conceptualised the Neolithic as a series of technological, economic and social revolutions in Southwest Asia, Vere Gordon Childe (1958.76-79) introduced the premise that pottery making was perhaps "the earliest conscious utilization by man of a chemical change" associated with "thinking of creation" and "making form where there was no form". The result was the ceramic vessel - a tool for more intensive food processing "made by women and for women". He suggested that pottery making was one of the steps in the progress of thoughts, knowledge, and skills that humans made as members of society in creating a culture as a kind of mental matrix for action, which allowed man to "make himself".

Ceramics soon become broadly considered a key materiality, taken to represent progress in econo- mic, technological, and evolutionary terms. The innovative linking of their plastic medium of clay and pyrotechnology to invent fired clay technology, and to create a solid object, a ceramic container, is still assumed to be a revolutionary step in the development of modern human thought and practice, taken along with agriculture and sedentism (Gamble 2007. 10-32).

We show bellow that the earliest step in the development of ceramic (pyro)technology in Eurasia was not the invention of vessels made from fire-hardened clay, but of cones, anthropomorphic and zoomorphic figurines, which were certainly not associated with (pre)existing container or any other food storage technology. The twenty-millennia-long episodic preNeolithic trajectory of the fired clay figurine tradition in western Eurasia did not lead to the innova- 
tion of ceramic container technologies. In Central Europe the focus in the Palaeolithic was on figurines and cones, followed by the first vessels production in the Pre-Pottery Neolithic in the Near East. In the East Asia, the focus was on vessel making from the outset. The western tradition predates the eastern by about eleven millennia. While ceramic cones and figurines first appeared in Europe at $c .31000 \mathrm{cal} \mathrm{BC}$, the earliest vessels in southeaster Asia are dated to c. 20000 cal BC (see below). Residual analyses show that they were used for food preparation and perhaps for storage tasks.

However, it was suggested recently that man "did not make himself" (Olsen 2010.9-10). Societies consist of myriads of co-working entities comprised of both humans and non-humans, and 'things', all those physical entities we refer to as material culture, are beings in the world alongside other beings such as the humans, plant and animals, which constitute the very basis of collective action and society. Emile Durkheim (2005.278) indeed suggested a century ago that "... it is not true that society is made up only of individuals; it also includes material things, which play an essential role in the common life. The social fact is sometimes so far materialized as to become an element of the external world.'

The making of pots was suggested to be closely connected with a new understanding of the 'co-dependency of mind and matter' that 'shaped the human intelligence' in the Neolithic. The shaping of ceramic vessels was correlated with conceptual innovations, a true three-dimensional conception of objects. The introduction of a different topology, 'a surface around a void', thus required the conceptual separation of the surface of an object from its volume, and distinguishing between interior and exterior surfaces (Read, van der Leeuw 2008.1965).

\section{Pots as bodies}

The perception of human dependence on, and mixing with, things at the level of being was embedded in the phenomenology of Heidegger and MerleauPonty. Martin Heidegger (1971.25) introduced the concept of the 'thing' and the 'thingness of the thing', suggesting that a thing is a totality - "the unity of a manifold of what is given in the senses". The jug is a thing, as a vessel, he suggested, made from earth, which stands on its own and takes on the task of containing water and wine, which come from a rock spring or from rain, or from the grape growing from the earth. Pouring can slake human thirst or be a libation to the gods. The jug thus connects humans, gods, earth and sky. It is this "gathering and uniting" that makes the jug a thing. The central aspect of the phenomenology of Maurice Merleau-Ponty (2005) is everyday practical experience of the world and things. Perception, he suggested, is not a matter of intellectual contemplation, but of active involvement with things - bounded entities that endure through time. It is the perception of the unity of the body that gives unity to the thing. It is through our bodies that, as humans, we are placed in the world, and this bodily being in the world must be understood through tasks and actions that have to be carried out, and through the material possibilities open to the body. So we may hypothesise that the pot has agency and does things for humans (Gell 1998), and acts as a "delegated non-human character" (Latour 1992.157).

It was not only knowledge of the properties of clay and fire, but the perception of containment that marks pots, suggested Carl Knappett et alii (2010). It was also the blending of pots and bodies. He noticed that, once ceramics were first introduced in Neolithic in Europe and Near East, they were associated with two major forms of 'containment'. The first is that of the vessel and the second of human and animal clay figurines. While in the first the association with containment is obvious at the functional level, in the second it is achieved through the semiotic relation with the human and animal body, which provide metaphors of containment.

Knappett also hypothesised that it was not only the perception of clay vessels capacity to contain, but rather the interactive properties, possibilities, or affordances that emerge because of this capacity of the vessel. Containers are thus not simply vessels, but action possibilities that make possible new forms of mediated action, agency, and material engagement, both in terms of use and manufacture (Knappett 2004; Knappett, Malafouris 2008). He introduced the relational concept of 'affordances' of objects, suggesting that information and meaning reside in objects and in the mind, since objects in context afford particular sets of actions to humans. 'Affordances', he suggested, frame, while not determining, the possibilities for human (agent) action in relation to objects (Knappett 2004.40). In other words, objects are a "sort of nexus, where mind, agency and material meet and merge" (Knappett 2005.57). He strictly followed Ian Hutchby's (2001.444) notion that "affordances are functional and relational aspects which frame, while not determining, the possibil- 
ities for agentic action in relation to an object. In this way, technologies can be understood as artefacts which may be both shaped by, and shaping of, the practices humans use in interaction with, around and through them". Hutchby termed his approach the 'third way' in the discussion in sociology of scientific knowledge. He embedded it between technological determinism and constructionism. The perception that new modes of social relations are actively caused by particular forms of technology relates to the first way. The second relates to the perception that technological artefacts are entirely socially shaped, in terms of both their form and meaning.

It is worth remembering that the conceptualisation of affordance (possibilities or opportunities), was introduced by James J. Gibson (1979.16, 23, 127-143) in ecological psychology, suggesting that the mind directly perceives environmental stimuli without additional cognitive construction or processing. He criticised the dogma that the human perception of function is indirect, being mediated by cultural representations. He strongly argued that objects held 'potentialities' (i.e. affordances) for a 'particular set of actions' that can be observed without categorisation related to actual cultural knowledge. Within the terrestrial environment, affordances were conceived as a "triad of medium, substances, and surfaces that separate them and where most of the actions are". The surfaces mark the layouts of objects that afford manipulation. Containers and pots are listed among many others. They all have their technical 'properties or qualities', but "what we perceive when we look at objects are their affordances, not their qualities", suggested Gibson (1979. 134).

Knappett et alii (2010.585) later replaced 'affordances' with 'containment', which they suggested is a better term for both 'action possibilities' and 'affordances'.

In parallel studies in anthropology, perceptions of containment were associated with 'bounded object'. They both related to pottery, an archetype for actions of containing, storing, pouring, mixing, and to cooking in the context of domestic technology evolution and food processing. The vessel was conceptualised as "a necessary extension of the body" in eating, drinking and other bodily functions, and associated with "a sensori-affectivo-motor conducts, individual desires and emotions" in daily household activities (Warnier 2006.193-195). Jean-Pierre
Warnier linked the body and material culture with "a major change in the domestic technology of containment" and "daily household activities" that evolve gradually in a "technology of power".

In the context of embodied mind theory in cognitive science, Mark Johnson (1987.21) suggested that one of the most pervasive features of our bodily experience is our encounter with containment and boundedness'. He linked the conception 'of bodily origins of meaning and thought with the intimate awareness of our bodies as 'three-dimensional containers into which we put certain things and out of which other things emerge'. He recognised the human body, and the house, as 'typical schemata for physical containment' that consist of a boundary that demarcates an interior from an exterior.

However, the container metaphor concept and embodied mind theory were linked to our conceptual system, in terms of which we both think and act, and is fundamentally metaphorical in nature (Lakoff, Johnson 1980; 1999). They were linked, as well, to our knowledge - we organise by means of structures called 'idealized cognitive models' (Lakoff 1987). These both related to Kant's concept of 'schemata' as structures of imagination and cognitive universals. In Kant's theory of perception, the 'schema' is not an image, but 'procedures for constructing images', thus involving perceptual patterns in our bodily experience. It is a nexus between a pure concept and a phenomenon (Johnson 1987.21).

In a philosophically oriented discussion of materials, their transformations and affordances, Tim Ingold $(2006$; 2007.35) suggested that there is no inside or outside, and no boundary separating the two domains. Instead, there are relations along which materials flow, mix and mutate. Persons and things, then, are formed in the 'meshwork' of relations between persons and things and things and things along which materials flow, mix and mutate. In 'animic' perception and lines of relationships, it is "a meshwork of interwoven substances". It is not that things are entangled in relations; rather, everything is itself an entanglement, and is thus linked to other things by way of the flows of materials that make it up. 'Affordances' were thus related to skill practices. Each generation, he claimed, thus contributes to the next "by introducing novices into contexts which afford selected opportunities for perception and action, and by providing the scaffolding that enables them to make use of these affordances" (Ingold 2000.353-354). 
In more simplistic perceptions of containment, both the human body and the Neolithic pot were considered as containers of fluids and substances which enter and flow out of them, with their orifices, entrances and exits. It was suggested that the surface acts as a human (Tilley 1996.318, 323-327) or animal skin (Mlekuž 2007.273). A more formal linkage was believed to be provided by the "occurrence of face pots with eyes" and clay temper consisting of crushed human bones (Tilley 1996.318). These vessels were recognised as food containers linked to feasting and ritual. The pots, although fragile, were hypothesised as representing a highly symbolic items, along with exotic food that would be associated with feasts and ceremonial events to celebrate ancestral forces and powers on the one hand, and to entertain and impress neighbours, and to rise within and between group competition for prestige, fame and power on the other. Pots were believed to act as 'metaphorical vehicles' that link 'notions of time and death to the human body itself through the process of burial ritual' (Tilley 1996.114).

The even simpler idea that some pots represent people was introduced by Ian Hodder (1988.382). It was based on southeast European Neolithic pots that occur in the form of a female body "with breasts,

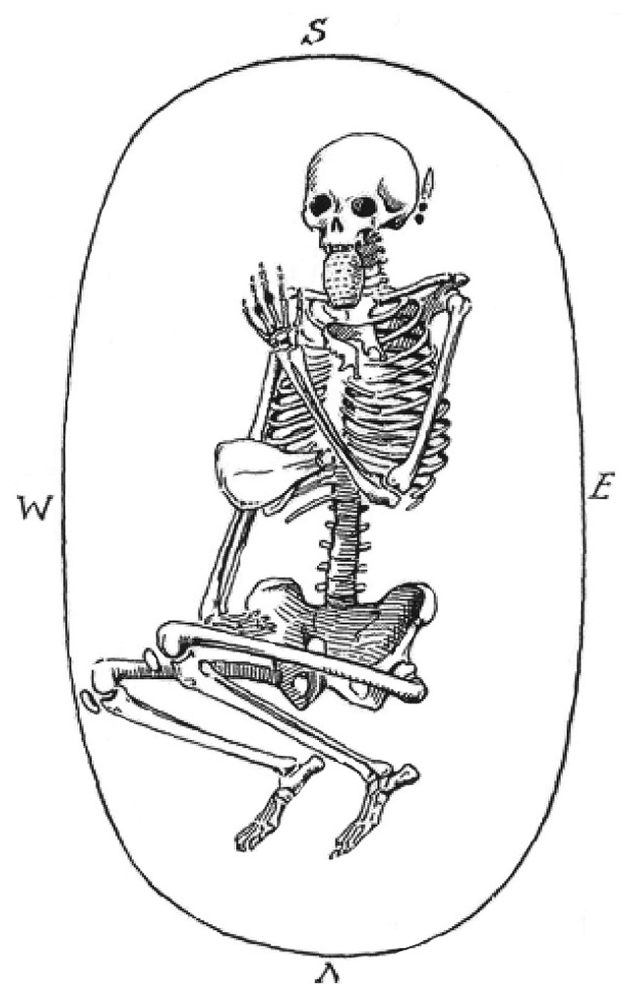

Fig. 1. The Bronze Age burial at Garton Slack. The mandible of the deceased was removed, and a vessel was inserted into the mouth (from Brück 2006a. Fig. 4). arms, and feet, and there are similarities in the decoration used on pots and on female figurines". Conceptualising the idea of 'entanglement', he explained that "objects that stand up against humans can only be known by humans through their character as things that gather humans and other things into heterogeneous mixes" (Hodder 2012. 13).

Sometimes pots became a part of the human body. In a Bronze Age inhumation burial, the mandible of a crouched inhumation was removed. It was then placed on the deceased's chest and a miniature vessel inserted into the mouth of the deceased (Brück 2006.84) (Fig. 1). An early Neolithic vessel modelled in the form of a headless female body contained a fragment of a human skull (Kalicz 1980.23, Tab. 2) (Fig. 2). The vessel could be seen as "mediator in their own right, object as person, whose major concern was the regulation of flows of substance" (Fowler 2004.63) or 'as containers, just as the human head is seen in many societies as the repository of the human soul' (Brück 2006.84). We may suggest perhaps that the vessel and the skull fragment metaphorically build a new composite body of the deceased.

John Chapman $(2000 a ; 2000 b)$ suggested that pottery is a medium that is 'reliable and effective' for holding persons and groups together "through the objectification of common traditions often reinforced by symbolic decoration", and for providing "a mechanism for symbolism of fission and rupture". Thus, complete pots may represent group solidarity, integration and successful constitution, whereas fragmented pots represent rupture, cleavage and friction, which lead to dissolution. In Early Neolithic societies, where household and/or local lineage institutions were weakly developed, the only way to maintain social reproduction lay in repeated social practices, including the smashing of pots. Thus, "the decision to keep pots whole through daily use is a metaphor for maintenance of social relations through continual renegotiation. Just as the associations of its various uses bring and added value to a vessel, so the enchainment of fractal person to a ramifying group of kin brings such people fame and reputation. Conversely, the rupture of those social relations characterising a less sedentary community would have elicited the response of the fragmentation of much valued pottery. But the even more striking collapse of social relations in a seemingly more stable sedentary community's may well have led to the large-scale fragmen- 


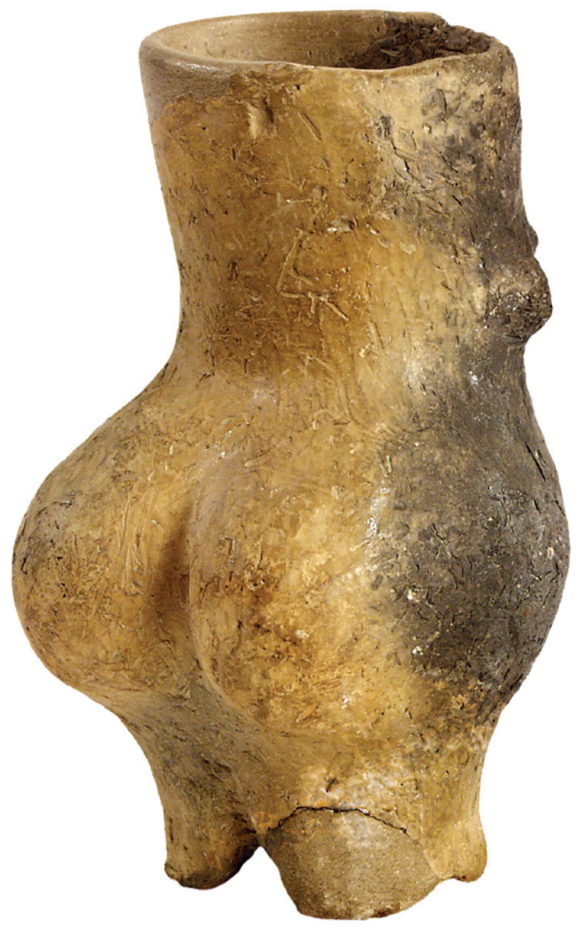

Fig. 2. The Early Neolithic 'Gorsza Venus' anthropomorphic vessel portrays a headless female body, and contained a fragment of a human skull (Kalicz 1980.Tab. 2).

tation of one of the that community's important symbolic resources-pottery" (Chapman 2000a.43). Along with the (fragmented) vessel, which mediates personal relationships between living members of society, human bones are a metaphor for maintaining relations between the living, the deceased and the ancestors (Chapman 2000a.144; 2000b; Chapman, Gaydarska 2007.53-70). A social practice of enchainment in this context is believed to comprise the best, and sometimes the only, explanation for the deliberate fragmentation of pots and bones (Chapman, Gaydarska 2007.203; Chapman 2008.188). In these readings, the fragmentation of vessels and bodies, and the extraction of parts from wholes and re-articulation of fragments in new units is the major mode of social relations through which people and things are constituted. People are not so much individuals as 'fractal' and 'dividuals'. Who they are and what they do relate to their transactions with each other, with material culture and with the dead (see Budja 2012.144-147).

We may hypothesise that the female body was not the only source metaphors of 'containing' through which Neolithic farmers experienced being and understood the world around them, but the animal body too. These appeared in the form of rhytons, four-legged vessels embedded in Neolithic contexts in the Balkans and the Adriatic. They have been seen as stylised representations of the lower body of different species of domesticated animal, especially sheep, goat, swine and cattle ( $P e$ rić 1996). It has also been suggested that they have some iconic resemblance to animals, which is not intended to be representational, but to reveal their hidden properties (Mlekuž 2007). Representations of wild animals appeared along with representations of domestic species. Maria Gimbutas (1989.Fig. 186) recognised a 'Bear Mother' in one of them (Fig. 3). However, domesticated animals are not only good to share households with (Haraway 2003). Neolithic personal experience may have been greatly shaped by the animals that people bred, exchanged and hunted (Fowler 2001.160). They were engaged in reciprocal social relations within the household ( $\mathrm{Na}$ dasdy 2007). In communities where personhood is stressed as a feature of the community and where a clan is a person (a family might be another), not all the people in the community are necessarily human, but other social agents, such as animals (for details, see Morris 2000; Fowler 2004.14-30; Voutsaki 2010.74).

\section{Pottery and women in ethnographic contexts}

Dean Arnold (1985.128-144) identifies a number of generalisations about pottery and people based on
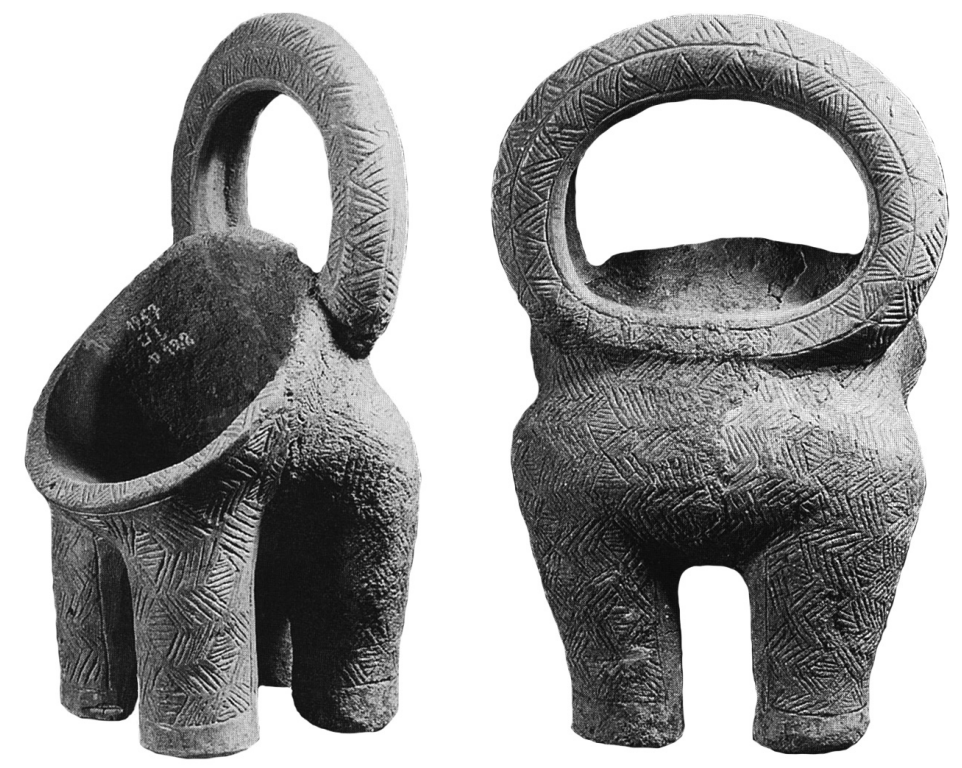

Fig. 3. The Neolithic 'bear-legged rhyton' from Smilčić. Maria Gimbutas (1989.118, Fig. 186) related its iconicity to 'Bear Mother' goddess. 
both ethnographic and archaeological observations. The two of most interest here are the relationship between pottery making and sedentism, and the correlation between pottery as a tool and more intensive forms of food processing. The perception of ceramic vessels as tools for more intensive food processing made by women for women soon became broadly accepted. It was even suggested that 'pottery is one of the few technologies controlled by women for millennia' (Longacre 1995.278). The idea that pots represent people has also been demonstrated for north-eastern Africa, where they supposedly act to order the social body there (Braithwaite 1982; Welbourn 1984).

The cross-cultural survey in Murdock's Ethnographic Atlas database of preindustrial societies indeed shows 105 traditional societies, $76 \%$ of which have female or predominantly female potters, $18 \%$ had male or predominantly male potters, and $6 \%$ have equal participation of men and women in pottery making ( $c f$. Skibo, Schiffer 1995.84). Paradoxically, in the same database, 282 non-sedentary societies were listed, 103 of which made pottery.

However, a number of ethno-archaeological and anthropological studies have pointed out the symbolic links between women and pottery. Studies suggest, "not only [to consider] woman to be the efficient cause of the clay pot but establish a symbolic identification between the two" (Lévi-Strauss 1988.180). Thus, Jibaro Indians in Ecuador believe that the vessel is a woman, and the Desana in Colombia and Brazil, that a woman's body is a cooking pot. Only women can create and use pottery because the clay, of which they are made, like the earth itself, is a woman. (Lévi-Strauss 1988.22, 181). Desana women have to collect the clay from certain places that lie outside their territory, but within the territory of other exogamous groups involved in intertribal marriage exchange. These groups are said to 'cook' their brides before the marriage exchange (Reichel-Dolmatoff 1978.280-282).

In sub-Saharan Africa the earth is similarly regarded as female, and potters may have special relations with it. On the other hand, a taboo against women's sculpting in hard materials such as stone, wood, bone, ivory, and metals compounds is suggested. Only men use these materials, and women may work only with soft, materials such as clay, basketry, gourds and leather (Teilhet 1978.97). In West Africa, female potting thus widely corresponds with male smithing, the potter being the wife of the blacksmith.
Among the Vere, the Dupa and the Dowayo in Cameroon, access to pottery manufacturing is always restricted to the wives of smiths. They are considered both dirty and ritually impure, and therefore subject to numerous taboos. They are marginalised and must live apart and may not enter the huts of others. They cannot share food or even draw water from the same spring, and never eat from the same vessel. Their separation is most strongly maintained by the belief that potters may harm others, as they may cause diseases. They are not allowed to own cattle, because of their "hot hands" (Barley 1994.64; Vander Linden 2001.140; Pankhurst 2003).

The Ari people in Ethiopia belong to either farmer's (kantsa) or craft workers' (mana) groups. The latter are socially segregated from the former, and it is taboo for kantsa to marry mana. Although potters, who are predominantly women, and blacksmiths belong to the same group, marriage between them is also prohibited. Potters usually work alone, although daughters are allowed to make pots in the same place as their mothers to learn "certain finger movement patterns as they play in their mothers' work places". There are no standardised procedures for pottery making, and each potter goes through trials and errors while creating their pottery. Based on their experience, each potter develops a unique procedure for making pottery (Kaneko 2007.6; 2009. 387). It has also been suggested that "the pots are widely assimilated to the person", and that the women who make these pots describe the different surface areas in terms of their own bodies (David et al. 1988.366; Welbourn 1984.20).

In Arnold's (1985.101) perception of "the beginnings of pottery as an economic process", it is suggested that women in hunter-gatherer societies were closely related to the household. He classified pottery production with 'pregnancy, infant care, cooking and other household tasks', because "pottery making is easily compatible with child care responsibilities"; it is "easily accomplished in the home and does not require periods of absence from the home"; it is "not dangerous and does not thus provide a hazard for children", it is "relatively monotonous and does not require great concentration, can be carried out in spite of interruptions and can be easily resumed"; and finally "once the process has begun, it requires almost daily attention and thus it is an ideal craft for females tied to the household".

Much later, taking a cross-cultural perspective, Randi Haaland (2009) similarly argued that vessels become 
particularly important in activities associated with women and hearth-centred activities, including childrearing, water carrying, plant gathering, and food preparation.

Parallel to this, cooking technology that used ceramic pots may have resulted in greater equality between individuals in the nutritional value of foods consumed. Meat sharing practices among foragers may be nutritionally and quantitatively inequitable, with women typically receiving less desirable portions, even when pregnant or ill. Preparing a dish of meat and vegetables cooked slowly in ceramic pots could have improved women's access to critical nutrients by equalising the distribution of foods within a group sharing meals from a single vessel. Patricia L. Crown and Wirt H. Wills (1995a.175-180) also hypothesised that women preferred ceramic vessels to other containers (i.e. bags, gourds, baskets) or cooking pits, because they could achieve an 'economy of scale' in manufacture that was not feasible with other cooking technologies (i.e. boiling stones, for cooking clay balls in Çatalhöyük see Atalay 2005; Hodder 2012.151-195).

It has been suggested that women produce the tools they use for food procurement and processing, and pottery making might be embedded in a production sequence that involves food gathering, crop tending, harvesting, fetching water, food preparation, and cooking. James A. Brown (1989.215-216) argued that pottery has time-budget advantages for partly or fully sedentary groups, because there are women "who are occupied in a pattern of activities around the base settlement"; these "are tasks around which craft production of many types easily fits the odd bits of time left over", and "consequently, under these settlement practices, labour has negligible costs".

Plant cultivation and pottery production were simply added to foraging women's existing workload. However, a behavioural chain analysis of maize preparation among the Hopis in North America in 1900 reveals that women assumed fourteen tasks from harvesting to serving, with seven of these tasks being performed several mornings per week and four tasks performed twice daily. We may agree, therefore, that cultivation and pottery have not fitted easily into women's existing workload, although they depend 'on the time and labour of women' (Eerkens 2008.320).

The locus of pottery production shifts from women to men when access to traditional resources decreas- es and pottery production becomes a more profitable (subsistence) economic activity. A close link also exists between male and the introduction of the potter's wheel, which increased the efficiency of techniques of hand-made pottery (Stark 2003.205).

\section{Pottery in the transition to farming}

Three general scenarios are available about both the invention and adoption of pottery. The first relates vessels to the use and display of ritual-specific objects made of fired clay and the emergence of specialists, such as female shaman potters. The second suggest the early use of pottery in practical functions, like every day cooking and storage. The third emphasises its role in altering or sustaining social relationships.

Karen Vitelli (1999.188) found pots at the earliest Neolithic site in Franchthi Cave in Argolid, but with no evidence of cooking and limited volume capacities, insufficient for food storage. These pots, she argued, had a non-utilitarian function in ceremonies and rituals that may have regulated social conflicts at the onset of sedentism (Vitelli 1993.217). She hypothesised that women were probably the inventors and first practitioners of early Neolithic pottery making in Europe. They were "individuals with shamanic powers", she suggested, who had knowledge of the "the seemingly magical transformation that takes place during pottery firing" on the one hand, and of the "medical and psychoactive properties of plants and of altered states of consciousness" on the other (Vitelli 1995.62). She estimated an annual production of about 12-13 pots per year divided among five potters at Franchthi (Vitelli 1989.21; see also Perlès 2001.83). Similarly, in East Asia (China and Japan) and the Russian Far East, the earliest pottery appears only in very small amounts and at a few sites (Keally et al. 2003.9; Cohen 2013). It has been suggested that the vessels may not have been used extensively for everyday food preparation, and that it was a barely sustainable technology that persisted in episodic, low-scale usage. One thus might question how it survived and intensified later (Gibbs 2012.90; Gibbs, Jordan 2013.20).

It is worth remembering that Prudence M. Rice (1999. 1-54) at the same time introduced a more complex interpretation of the appearance of utilitarian pottery. She thought vessel production could be considered as a trajectory of a series of cultural transformations, beginning with resource intensification, through socioeconomic intensification, to technolo- 
gical intensification "as a prestige technology and a durable good". There were two different processes, 'initial emergence' ('invention') and 'adoption' ('innovation'), which can be separated by hundreds or thousands of years, she continued. While the invention' relates to processes of experimentation and precedents for ceramic technology (clay-lined baskets) and the social contexts in which these inventions appeared, the innovation concerned pottery's "wider incorporation into the container technology of previously non pottery-using societies". The innovation thus relates to the social and economic settings in which ceramic containers became 'watertight, fire-resistant' tools widely used for day-to-day cooking, food consumption and storage (originally suggested by Brown 1989.213-216). Rice hypothesised that pottery could have been particularly helpful for 'broad spectrum collecting' strategies, which include diverse foods that often might be seasonally available in only small but highly concentrated and highly predictable quantities, which can withstand high harvest rates, such as grains, beans, tubers, shellfish, etc. Such food must be cooked and requires sustained simmering or boiling water. Diet can thus be better controlled by preparing meals that included multiple ingredients (meat and vegetables). Boiling and the long-term heating of mixed ingredients improved nutritional intake and allowed an equal distribution of nutrients in a group. An additional advantage is that cooking vessels can be left untended for appreciable periods. She relates the resource intensification to the intensified exploitation of selected highly productive resources, and to the emergence of socioeconomic competition by 'aggrandizing' individuals or groups who competed for power, prestige, and status by means of competitive feasts. Pottery containers seem to have been most important for serving (display) rather than cooking or long-term storage. They became medium, both as prestige technology and containers of new, exotic (e.g., cereals) or perhaps highly desirable foods, for social and power expression.

Ingold introduced (1983.561-652) the 'social storage' aspect of food accumulation. This refers to the "... appropriation of materials in such a way that rights over their future distribution or consumption converge upon a single interest. In this sense, the store has to be considered in its aspect as property or wealth, and storage as a concomitant of social relations of distribution." It was hypothesised that food containers in this context represented a cultural code by which persons may be identified with their property. On the other hand, social stor- age represents the direct negation of sharing, which requires a 'practical portable storage, and much stricter calculation' of how much each individual is obliged to make separate provision for bad periods in the 'delayed return' systems of resource exploitation. Vessels offer the possibility of measuring produce in standard units of volume, and calculating how much each individual has given to, or received from, joint efforts. We may assume this distribution was an alternative to a general sharing of food that made possible the ideological transformation from hunting to farming.

However, behavioural ecology theory offers 'prey and patch choice' or 'diet breadth' as an extension of the microeconomic concept of 'opportunity costs' and 'delayed return food production' interpretative models, which suggest that the transition to agriculture "may have coevolved with incremental shifts from public to private goods" (Codding, Bird 2015. 15; see also Winterhalder 1983; Bird, O'Connell 2006; Winterhalder, Kennett 2006; Bettinger et al. 2010). Hunter-gatherers distribute resources in two different ways. Among immediate-return hunter-gatherers, there is no storage, and the day-to-day uncertainties of hunting and gathering require unlimited and uncontrolled access to territories and their resources, as well as widespread intragroup sharing of harvested resources. Land and resources are public goods, belonging to everyone. Resources should be freely used, redistributed, and shared to equalise disparities. Meanwhile, society should punish hoarders. Delayed-return hunter-gathers, however, accumulate and store some resources for future use and thus place limits on immediate consumption, often by privatisation, making them the property of those who obtain them. Resources thus belong exclusively to those who obtain them, and society should punish those who take resources garnered by others without permission.

These contrasting principles have supposedly had important implications for subsistence intensification. Open access to resources discourages intensive foraging, which is so costly that individuals will not risk it without an assurance that they can keep everything they harvest. This means they need some assurance that the very low returns they obtain will be safe from the claims of individuals who work less, but who always receive the same share as everyone else. If resources must be shared with freeloaders, harvesters of low-return resources may well end up expending more energy than they obtain. For this reason, immediate-return hunter-gatherers "restrict 
themselves to resources having returns high enough to offset freeloader overhead, using just enough low-return resources to squeeze by and punishing those who hoard them. This keeps population size and density low." (Bettinger et al. 2010.12). Delayedreturn hunter-gathers, however, target low-return resources, especially plants that are easily stored. This sustains larger, denser, and more stable resource populations, while reducing the payoffs to individuals who continue to specialise in high-return resources, the use of which can be sustained only by sharing.

Thus it has been suggested that delaying returns restructured prey and patch choice dynamics in a way that becomes contingent on social institutions that solve problems of collective action associated with stored foods, introducing 'farming-friendly property rights', and thus allowing low-level food producers to make the transition to rely completely on domesticates (Bowles, Choi 2013; Codding, Bird 2015). Incipient forms of privatisation were hypothesised as being associated with the appearance of storage pits full of uncarbonised broomcorn and foxtail millet in north China (Bettinger et al. 2010. 12). In the Western Great Basin in North America, privatisation was linked to the invention of ceramic vessels, which helps mobile groups to intensify 'wild seed' exploitation, a resource that can be individually acquired, processed and stored privately (Eerkens 2004, see below).

Following Pierre Bourdieu (1984), on the other hand, we can also see how feasts can convert economic capital into either symbolic power or cultural capital. Brian Hayden (1990; 1995; 1998; 2009; 2011; 2014) introduced this perception of feasts into archaeology, strongly emphasising the social implications of early pottery use and exotic food consumption in the context of transition to farming. He thought the association of ceramic containers and feasts may even reflect a universal cultural tradition (Hayden 1998). He made a clear distinction between practical and prestige technology. The first is based on the principle of performing tasks in the most efficient and effective fashion possible, which means the less time and work involved, the better. In contrast, prestige technology is grounded on displaying one's wealth, power, or control over labour and resources. Its appearance, he suggested, reflects 'economically based competition' that is possible only when technological advances occur in surplus food production and storage.

\section{Pottery and 'aggrandisers'}

To answer the question 'Why clay pots?', Hayden (2003) suggested an economically oriented sociopolitical scenario based on the interconnected concepts of 'private ownership', 'economically based competition' and 'prestige technologies' which appeared among 'transegalitarian' hunter-gatherers. The term 'transegalitarian' refers to societies that recognise private ownership, use prestige items, produce some surpluses, hold feasts or other economically based competitive displays, have restricted sharing, and a range of poor and wealthy families that do not form permanent classes. They differ from societies with permanent classes and political hierarchies on the one hand, and egalitarian societies on the other hand, where sharing is mandatory and there is essentially little or no private ownership or economically based competition. Hayden postulated that feasting constitutes a new kind of human behaviour that probably first emerged in the Upper Palaeolithic, and that it can be "intimately associated with the first specialized structures, often referred to as communal buildings or ritual structures", where "surplus food can be converted into other desirable things or relationships in short spans of time". Feasting, he continued, provides the 'underlying dynamics for the development of a range of prestige technologies, including new food preparation and serving technologies, including pottery'. In this context, the domestication of plants and animals were "the most important prestige technologies to have been developed specially for feastings" (Hayden 2014.4; see also Benz 2015).

Hayden (2011) hypothesised that the transition to private property emerged under conditions of resource abundance, where everyone could have been assured of enough to eat under normal conditions. However, the ability of a technology to extract and store surpluses from environments with abundant resources was required. If not, 'technological bottlenecks' could have occurred in the procurement, processing, or storage of seasonally abundant resources. Storage also led to seasonal, and in some cases perhaps prolonged sedentism, as well as favouring notions of private property, since stored foods represented a supplemental investment of labour by individuals or households for their own benefit, whether in terms of reproduction, power, survival, or standard of living.

He proposed that the development of feasting among hunter-gatherers constituted a new phenomenon 
that could have motivated people to develop new technologies. These technologies included not only new extractive devices (such as fishhooks, nets, leisters, sickles and weirs), but also new processing tools (such as grindstones, boiling stones and earth ovens), and new storage technologies. In favourable areas, the cumulative effect of these innovations was to make the production of surpluses relatively reliable. The surpluses were owned by individuals or families and used by them in strategies to enhance their own survival and reproductive benefits (Hayden 2009).

These individuals are recognised as 'aggrandisers', or "triple A personality types: ambitious, aggressive, accumulative, aggrandizing, abrasive people" (Hayden 2011.115). They invented a number of strategies for converting food surplus production into social and political ties through the creation of debt relationships and the display of mutual support. The most common and most important of these strategies include the hosting of feasts with obligatory reciprocity as a way to indebt people, and the creation of wealth (or prestige) objects (such as ceramic vessels) used to validate social transactions with obligatory returns, thus creating debts and forcing people to produce surpluses. The pottery consists of finely-made serving vessels or vessels used to produce special foods. They all exhibit new and prestige ceramic technology to be used to produce prestigious materials and foods to impress guests. Ceramic containers thus became a medium for 'aggrandisers' to build political alliances and court potential followers during public gatherings. Christopher Garraty (2011) suggested that these prestige technologies became widely imitated and in time reinvented as practical technologies.

The quantity, shape and size of pots associated with luxury foods formed an important indicator of household status (Hayden 2001.59; 2003.458-469; see also Van der Veen 2003.405-427). The quantity of pots may indeed signify the use of ceramic vessels as status indicators. Exceptionally large vessels may point to the occurrence of communal feasts. A change from large communal pots and serving bowls to the use of individual plates, drinking vessels and cutlery may indicate a change from eating from a communal bowl to serving portions to individuals and to a shift to hierarchical feasting. The development of social complexity is often viewed as one in which feasting becomes increasingly associated with elites. Paul Halstead (2012) thus recognised Neolithic equivalency feasts as a basis upon which Early Bronze Age palatial hierarchical commensality developed.
However, we may assume that hierarchical feasts that evolved from community feasts should not be limited by the assumption that hierarchical feasting replaced all other forms of commensality comprising larger than regular meals, but smaller than the material signatures of very large community feasts (Twiss 2012; Smith 2012). In societies undergoing a transition to greater complexity, the functions of solidarity and the creation and demonstration of numerous crosscutting ties would have been of increasing importance to households as well as to emerging elites. Feasts would have been demonstrations 'of individuals' and households' ability to mitigate failure, to demonstrate their resilience in the face of anxiety and stress, and to manage the memory-making of events after the fact" (Smith 2015.1230). Feasts are complex events in which success is far from guaranteed, and the many points of potential 'feast failure' provided an essential opportunity for continuously demonstrating social ties.

Following Hayden (2003.466) "many of the first domesticates in most regions of the world are clearly luxury foods or prestige items". These foods were "the rarest, the most difficult to procure or the most-labour intensive to produce, together with labour-intensive preparations" (Hayden 1996.137). His main argument on subsistence intensification does not concern food shortage, but the desire to quickly produce more cereals or animals suitable for feasting to obtain social and political advantages. It was in interests of aggrandisers to reduce the cost of these foods where possible. While this is initially beneficial to them, it changes the status of such foods in the long term and thus their value in prestigious displays (Hayden 1998). Exotic foods were desired not so much as foods, perhaps, but as symbols, as 'markers of social distance', and 'status indicators' (van der Veen 2003.415).

The competitive feasting scenario was related recently to behavioural ecology theory. Douglas Bird and James 0'Connell (2006) suggested that 'costly signalling theory' and 'irrational behaviour' can explain the conditions under which high-cost, status-related food production and distribution might be expected to develop. Luxury foods were generally characterised by the cost of acquiring or producing them, and by the notion that they are functionally unnecessary. The cost of producing such foods often limits their distribution to special occasions that can be arranged only by those who can afford them. Those unable to engage in feasting are marginalised, and even forced into slavery. The roles of status, the pro- 
duction of costly foods and feasting have been suggested as initiating the development of despotic corporate groups, control over the labour of others, and the evolution of hereditary and inequality in social stratification.

To answer the issue of what kinds of 'meant-toimpress foods' could have been prepared in the earliest ceramic vessels in Incipient Jōmon sites at $c$. 13 100-11 000 cal BC, Oliver Craig et alii (2013) suggest that freshwater and particularly marine organisms were processed, even though neither site is situated directly on the coast. Similarly, the presence of lipids derived from aquatic organisms in the large number of hunter-gatherers' pottery in north-eastern North America and in Northern Europe show that ceramic vessels developed in this region valued exchange commodities, such as fish oil, at episodic social gatherings during periods of high resource abundance (Craig et al. 2011; Taché, Craig 2015). Similar evidence has been provided by Alexandre Lucquin et alii (2016). There was little indication that ruminant animals or plants were processed in pottery, although it is evident from the faunal and macrobotanical remains that these resources were heavily exploited.

A recent residue and use wear analysis of grindstones associated with the initial pottery at the Nanzhuangtou site in northern China shows they were probably used to process the seeds of a range of wild grasses (including millets), acorns, and tubers (Cohen 2013.69; see also Liu et al. 2013).

It is interesting that Fumiko Ikawa-Smith (1970) argued decades ago that pottery was adopted in the initial Jōmon in response to rising amounts of shellfish and other aquatic foods. She suggested that pottery was adopted because it allowed better ways of direct cooking. Some other 'adaptationist' views saw the earliest pottery in the North American Midwest as a specific response to the need for more efficient containers for the extraction of oils from nuts $(\mathrm{Oz}$ ker 1982), or because cooking pots permit a wider range of food resources and techniques of preparing and processing foods to be used (Reid 1984; Arnold 1985.128-44).

\section{Pottery and food resource intensification in hunter-gatherer societies}

James Brown (1989.208-212) suggested, contrary to Hayden, that the earliest pottery 'should be processing vessels' and not 'food-serving containers as- sociated with the tendency for increased economic competition along with more pronounced inequality'. He postulated that early pottery appeared in two separate contexts: sedentary cultivators who used the vessels to process and make digestible cereal grains, and seasonally sedentary hunter-gatherers who used vessels with either direct or indirect heating to extract additional nutrients from animal products or to process seeds and nuts more effectively. The adoption of ceramic vessels thus becomes an innovation, he suggested, in households where 'watertight, fire-resistant vessels are in greater demand than existing sources of supply can deliver'. This demand increases with new processing needs for smallsized seeds and nuts, of which cereal-grain processing is the most demanding of all. On the other hand, sedentary and partly sedentary settlement systems foster the adoption of pottery "... due to the cheapness of this craft as an alternative to other container crafts when a constraint is approached in the available time that a craftsman has at his or her disposal to dedicate to non-ceramic vessel production. My basic proposition is that pottery, even as a crude technology with limited applications, has an advantage over other alternative containers, even sophisticated basketry, when budgeting time-resources conflicts with or impedes the production of non-ceramic containers." (Brown 1989. 222). In other words, pottery making is only useful when the demand for vessels is high, and large numbers can be produced in a single firing event. Firing is one of the most time-consuming and energy-consuming steps, and can be done almost as easily for one pot as for many. In economics terms, the perunit cost decreases with increasing output, a result that is not true of other container technologies, such as baskets, stone bowls, or wooden bowls, where items are made one at a time at the same per-unit cost regardless of total output. As a result, pots, which may be weaker and shorter-lived than these alternative containers, are preferred because large numbers can be produced at once (Eerkens et al. 2002).

Seasonal sedentism at least was required for pottery making. Because of scheduling conflicts, mobile hunter-gatherers may not be able to stay in one place long enough to complete the pottery production sequence, from collecting clay to forming pots, drying and firing them. It can take from several days to several weeks. It is worth remembering that in many parts of the world (like Siberia and the Russian Far East), pottery can be made only in one season of the year because the climate is otherwise too cold and wet (see Zhushchikhovskaya 2005.36-44). 
On the other hand, it is often said that the adoption of costlier subsistence technology marks an improvement in food procurement. Better tools make the process more efficient: maximising the rate of nutrient acquisition improves health, either by increasing nutrient intake or by reaching some intake threshold more quickly, thus freeing time to pursue other subsistence activities. This is true in the sense that new technology often enables its users to extract more nutrients per unit weight of resource processed or area of land harvested. If we focus on efficiency, and on the cost/benefit ratio as the key criterion, i.e. the rate of nutrients gained relative to the effort needed to acquire them, then the use of costlier tools will often be associated with declines in subsistence efficiency (Bird, O'Connell 2006).

Jelmer Eerkens (2004.661-663) linked pottery innovation among mobile, non-farming groups in the Western Great Basin in North America to the intensification of wild seed exploitation. He related it to a dietary shift from less predictable, frequently shared foods associated with a group-based procurement and cooperation (meat) to more predictable, infrequently shared particulate plant foods that were conducive to individual, or family-based procurement, such as cereal grains, starchy seeds, nuts, kernels, and legumes. Although meat sharing was common among hunter-gatherer groups as a means of reducing risk and garnering social recognition, families were not obliged to share more predictable and readily stored plant foods. Unlike most hunting activities, foraging for these foods did not require collaboration or mutual assistance among group members.

It is also worth mentioning the positive correlation between pot use and the preparation of easily digestible gruels that can substitute for mother's milk. It has been argued that the processing of such gruels facilitates earlier weaning and improves infant survivability, both of which act to increase populations (Crown, Wills 1995b.248).

Eerkens (2004) suggested that the ethnographic record demonstrates that seeds, which were prepared in pots, were largely considered private goods. However, whether pots were instrumental in the privatisation of seeds or were adopted to process an already privatised resource is unclear. Because pots can be individually made and used inside houses, they are well suited to privatisation. Vessels were differentially used within households, out of view of the rest of the community, and they were not on dis- play. This probably also explains why most pots were not decorated.

Pots make very durable containers resistant to boiling and other hard and permanent use; however, they are less portable and more inclined to break than other containers. Cooking pots are subject to repeated thermal and mechanical stress and, therefore, tend to break and require replacement more frequently than storage and service vessels. Because of conflicts between weight and fragility, bigger storage vessels may have simply not been moved at all. Although it is broadly accepted that hunter-gatherers do carry vessels with them, and that sedentary peoples often transport pottery over long distances, one solution to the weight and fragility problem is simply not to move the pots at all. It has indeed been suggested that 'caching pots' may have been a used to avoid carrying pots during the seasonal round, thus making the technology worthwhile (Eerkens 2003).

'Caching pots' or temporary storage strategies may have had major consequences for the lifestyles of hunter-gatherers, since they could not have deposited pots anywhere in a field. Caching would have tied people to particular places on the landscape where they had deposited pots. This results in higher rates of site re-occupation, also referred to as 'occupational redundancy' or 'persistent places' (Eerkens 2003). Such ties may have promoted reliance on foods associated with these locations and may have encouraged the notion of land ownership and territoriality. At the same time, it is also likely that 'caching behaviour' would have prompted people to modify pottery technologies to make their products more suitable for storage during the off-season. Thicker and stronger pots may have been a by-product of this behaviour (Eerkens 2008).

The early introduction of container technology was based on 'family-by-family decisions' within a context where pottery-using families were living in close proximity to non-using families. Even on a small scale, families might have adopted pottery at different rates and for different reasons. 'Dependent pottery invention' thus marks a process in which households adopt technical knowledge from an external group, but modify or 'reinvent' it in a way that is foreign to the donor population. Households in different areas may have adopted and 'reinvented' pottery in response to different local needs. The appearance of ceramic vessels seems to follow the 'diffusion of innovation principle', with small numbers of early 
adopters, followed by a rapid increase in technology adoption, and again with small numbers of late adopters (Garraty 2011.223; Eerkens, Lipo 2014).

Pottery may indeed have first been used for storage to better protect seeds from the adverse effects of temperature fluctuations, moisture, and bacteria (Diehl, Waters 2006.80-81), but was converted into cooking pots elsewhere after a long period of experimentation. Eerkens (2008.320) suggested that baskets which were woven so tightly they could hold water and could be used to cook and serve foods were replaced by ceramic vessels because the boiling of small seeds became a major cooking activity. That is, stone boiling in baskets demands constant attention from women to replace cooled stones with heated ones and to avoid holes being burnt in the bottom of the basket. So pots provided a more efficient boiling container, because they can be set over a fire with less attention and more seeds could be processed.

In most regions in the southwest of North America, most pots were locally made and used. Two or three different pots per house were used during a limited time of the year. Similarly, 'caching pots' were probably only used at certain times of the year (Eerkens et al. 2002).

It is worth noting that maize cultivation preceded pottery making in southwest North America. While cultivation appeared in a 'Pre-Ceramic interval', the initial appearance of ceramic technology was first documented in the 'Early Agricultural Period' at $c$. $2130 \mathrm{cal}$ BC (Huckell 2006; Mabry 2006). The introduction of ceramic technology relates to the production of anthropomorphic figurines; at some sites, these are associated with very few, very small ceramic vessels. The latter have been defined as 'incipient plain ware pottery'. They are small, low-fired, and have simple forms. They have highly variable vessel wall thickness, textural surface treatments such as incising, punctuating, and impressing, and the rare use of slips or paint. Individual or small group serving vessels dominate assemblages, followed by and storage and cooking pots (Heidke 2005; 2006; Mabry 2005; Garraty 2011; Eckert 2014). Almost half of the early ceramics were deposited in contexts interpreted as having a ceremonial, ritual, or integrative function. Some are associated with 'Big Houses', which are up to three times larger than other structures (Heidke, Stark 2002).

The various interpretations mentioned above suggest that pottery technology may have appeared on the one hand in association with temporary storage strategy, seed protection and resource intensification; with the evolution of territoriality and land ownership hunter-gatherers perception; householdlevel control of resources and private property protection. On the other hand, it may relate to the evolution of culinary practices; 'economy of scale' and women's workloads within households; aggrandising behaviour, competition and individual self-interest to produce surpluses, prestige, power and status.

\section{The origins of ceramic technologies in hunter- gatherer societies}

We mentioned above that current evidence increasingly reveals that hunter-gatherer societies developed ceramic technology a millennia before the earliest Neolithic and the beginning of sedentism and agriculture in Europe and Asia.

The invention of fire-hardened clay enabled huntergatherers to make durable products, whether ceramic containers or ceramic human and animal figurines. It was recognised as an early step in the development of pyrotechnology. It might have been related to 'cross-craft interactions', a copying of shapes and designs from one material (baskets, ground stone and wooden bowls) to another (ceramic vessels). This kind of transmission is known as skeuomorphism and may occur several times within a similar timeframe, and has been proposed for both ceramics making and copper metallurgy (Miller 2007. 238; Frieman 2013; Roberts, Radivojević 2015; Radivojević 2015).

While pyrotechnology is defined as "deliberate processes utilizing the control and manipulation of fire" (McDonnell 2001.493), the transformation of matter requires not only a working memory and understanding of the separation between different stages of complex production (Read, van der Leeuw 2008.1965), but also a shift in perceptions of the natural environment and the 'animate' qualities of soils and minerals, which often relate to 'ritual journeys' for mineral acquisition (Boivin 2004).

Benjamin Roberts and Miljana Radivojević (2015. 300-301) suggested recently that two processes, invention and innovation, underlie the appearance of pyrotechnologies in prehistory. They both related to ceramic making first, followed by copper metallurgy. Invention is defined as the discovery of a new idea, material or process, deliberately or by chance, and may include a radically new product as much as a 
recombination of technological components in a novel manner. An innovation is recognised when "an invention affects the evolution of the system and is successfully transmitted within a population, and beyond".

The invention of any novel technology evolved through an accumulation of knowledge of the process's components accumulated through experiment, recombination or reapplication over a period of several decades, or centuries. It may have taken a few generations of people before the invention developed and until it reached a form that functioned for a desired purpose (Radivojevic 2015). Changes in material culture were thus more likely to have been built up over a certain period, rather than being radical technological breakthroughs (Shennan 1989).

To address the question of what motivates invention, John Lienhard (2006.117-118, 158, 165) suggested four major stimuli: profit, necessity, pleasure and freedom. He identifies three stages 'in the evolution of any technology': gestation, cradle and maturation. Gestation refers to a fairly long 'run-up period before the invention takes an identifiable form'. It is a period of creating a "capability that we strong$l y$ desire, without knowing what form that capability will take". During the cradle period, the inventor seeks to understand the invention and alter it in ways that make it serve a purpose. When the invention reaches a form that is no longer dramatically changed, the maturation period begins. The trajectory of technological evolution is very rarely completed during the lifetime of a single inventor. It could take a few generations of inventors, who contribute to the accumulation of knowledge before the invention is sufficiently developed to be broadly adopted. We may note that humans inherited a 'riskinnovative' behaviour, e.g., a capacity to invent and adopt innovations in stressful conditions, when individuals are more encouraged to be inventive in times of economic or environmental uncertainty or strong competition (Fitzhugh 2001). In the context of resilience and sustainability theory, a new technological invention can be linked to the ability of society to maintain sustainable development (Berkes et al. 2003; Smit, Wandel 2006).

Indeed, early pots are found only in very small numbers at Palaeolithic hunter-gatherer sites in East Asia. They remained confined to a small number of sites, and persisted in episodic, low-scale usage until the
Early Holocene (e.g., Keally et al. 2003; Cohen 2013). There seems to have been a relatively long and gradual 'experimental stage' (for concept see Jordan, Zvelebil 2009) that may not have involved significant dispersals of ceramic (pyro)technology and vessels.

The initial pottery in East Asia is chronologically embedded in time spans at 19 286-18 886 and 16138 $15962 \mathrm{cal} \mathrm{BC} 1$ in the Xianrendong and Yinchuan caves in southern China, and at 10 180-9691 cal BC at the Nanzhuangtou site in northern China; at 14986-13839 and 13855-13536 cal BC at the Odai Yamamoto 1 and Kitahara sites in Japan; at 14 139-14 297 and 13 735-13 354 cal BC at Khummi and Gasya in the Russian Far East, and at 12 20612034 and 12 106-11 688 cal BC in Eastern Siberia in Russia (for radiocarbon dates, see $W u$ et al. 2012. 1699; Cohen 2013.61-70; Hommel 2014.Tab. 30.1; Kuzmin 2015.Tab. 1).

Some of the earliest pottery fragments from Palaeolithic hunter-gatherer sites in East Asia bear zigzag, stripe or net impressions on the exterior and sometimes interior surfaces. Similar imprints can be made by various techniques for shaping vessels, such as beating out the walls of a hand-modelled vessel with a paddle wrapped in cordage or plant fibres; modelling a vessel inside a hard template or mould, such as a basket; or modelling a vessel inside a semisoft cord mould, such as a woven bag (Cohen 2013; for a detailed analysis of 'cross-craft interactions', see Zhushchikhovskaya 2005.21-23, 59-81; 2009; 2012). Some incipient Jomōn vessels have a square form that imitates the form of rectangular wooden trays or woven baskets (Gibbs, Jordan 2013.8).

It has been suggested that the invention of pottery in Southwest Asia (Near East) was related to preexisting (pyro)technologies, such as lime plaster production, and the production of ceramic figurines and tokens. Kevin Gibbs (2015.340) and Peter Jordan (Gibbs, Jordan 2016.31) argued recently that it represented 'a stage of innovation in the development of container technologies 'that was embedded in the evolutionary Neolithic triad of 'sedentism, followed by agriculture and pottery'.

Pots in East and West Asia were 'open fired' or fired in domestic hearths at low maximum temperatures between $450-700^{\circ} \mathrm{C}$, although the earliest pots may have been fired at temperatures below $250^{\circ} \mathrm{C}(\mathrm{Zhu}$ -

1 All radiocarbon dates in this paper are calibrated with $0 x \mathrm{xal} v 4.2 .4$ at $68.2 \%$ probability. 
shchikhovskaya 2009.126; Lu 2011.18; Cohen 2013. $66,77)$. Both types of firing produce irreversible changes in the clay body. The earliest invention of ceramic (pyro)technology in East Asia predates its appearance in the Near East by some ten millennia (Cohen 2013; Kuzmin 2015; Gibbs, Jordan 2016).

\section{The diffusion of ceramic technologies in Eurasia}

Fabio Silva et alii (2014) and Peter Jordan et alii (2016.590) recently hypothesised two independent centres of ceramic (pyro)technology innovation in hunter-gatherer societies, one in China and one in Africa, and that "the earliest European pottery traditions may ultimately find their origins in one or both of these". They suggested two diffusion zones of ceramic-making traditions out of the main centres. The northern tradition spread from East Asia across Siberia, the Russian plain, and much of the eastern Baltic, Eastern and Northern Europe. In the south, pottery spread with farming from the Near East to Europe, although in the Near East this may not have been the result of an independent local innovation, but may have been influenced by the early pottery traditions of North Africa.

Both corridors are related to modern biomes favouring the rapid diffusion of pottery making. While the northern corridor correlates with the distribution of "temperate broadleaf/mixed forest' and 'temperate grassland/savannah/shrubland", the southern corresponds to "Mediterranean forest/woodland/ scrub". The front speeds of diffusion through these corridors was calculated with regression analysis and statistical modelling of radiocarbon dates from
396 sites, with Xianrendong Cave in China and Saggai in Sudan being taken as the starting points of each diffusion. The rate of spread in the "Asian-origin diffusion zone is $1.2 \mathrm{~km} / \mathrm{yr}$ ", and $3.3 \mathrm{~km} / \mathrm{yr}$ in the African-origin diffusion zone (Jordan et al. 2016. 595-596, 598) (Fig. 4).

However, as to where ceramic technology first appeared, the answer becomes rather different when we shift the focus from the origin of the earliest ceramic vessels to the origin of ceramic figurine production in hunter-gatherer societies in the Old World. This occurred neither in East Asia, nor North Africa, but in Central Europe.

\section{The earliest invention of ceramic (pyro)tech- nology in the old World}

We suggest that the earliest step in the development of pyrotechnology in Eurasia was not the invention of vessels made from fire-hardened clay, but of anthropomorphic and zoomorphic figurines, which were certainly not associated with (pre)existing container or any other food storage technology. The earliest evidence of burnt clay is available in an Upper Paleolithic Gravettian (Pavlovian) context at Dolní Věstonice, and relates to non-figurative pellets and cones, dated to $30732-29956 \mathrm{cal} \mathrm{BC}(68,2 \%)$. They predate ceramic figurines and similar pellets at other sites by two thousand years. They were deposited very close to a central hearth and supposedly unintentionally fired (Svoboda et al. 2014.3, 76; 2015.202, Tab. 1). At later sites, hundreds of these were fired intentionally, with some bearing fingernail imprints (Händel et al. 2009).
Fig. 4. The Jordan' et alii 'modelled first arrival times' for the spread of ceramic technology and pottery from the two hypothesised centres of innovation, in Eastern Asia and North Africa. Authors: Jordan P., Gibbs K., Hommel P., Piezonka H., Silva F. and Steele J. 2016. Modelling the diffusion of pottery technologies across Afro-Eurasia: emerging insights and future research. Antiquity 90(351), p.599, Figure 4, reproduced with permission Cambridge University Press.

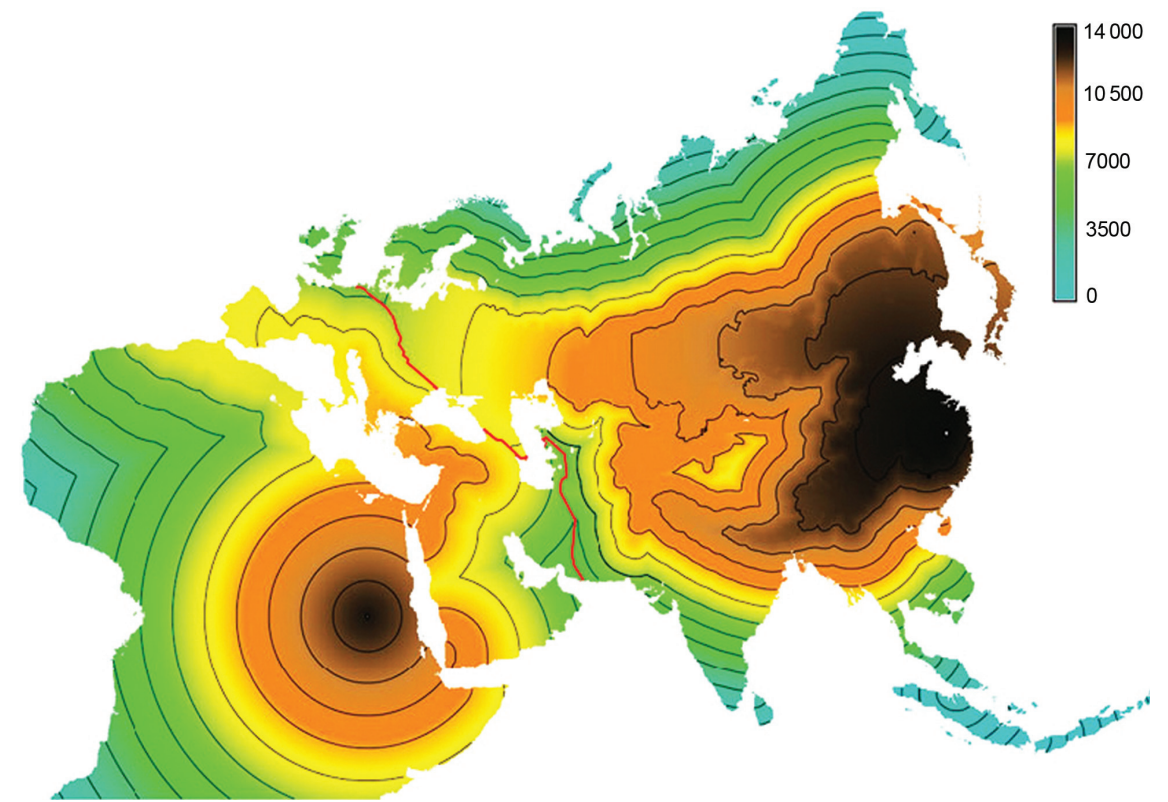


It is well known that some 10000 ceramic artefacts, among which hundreds of fragments of anthropomorphic and zoomorphic figurines and thousands of pellets and cones, have been found at large Gravettian (Pavlovian) open-air sites in central Europe (Verpoorte 2001; Králik, Einwögerer 2010; Králik 2011). These sites show evidence of repeated/episodic occupation, complex hearths, dwelling structures, burials, and innovations in weaving, pyrotechnology and ceramic making embedded in the period $c .31000-$ 27000 cal BC.

These figurative ceramics were made to be broken, according to Olga Soffer et alii (1993; Soffer, Vandiver 2005.424). Analyses indeed indicate that almost all the figurines and statuettes were deliberately fragmented, although most of the pellets and cones, which form a large part of the ceramic inventory, were found in an intact state. The analysis of ceramics suggests evidence of intentional thermal shock created by re-wetting air-dried figurines before they were thrown into a hearth. The figurines thus made a loud noise as they exploded, creating a sort of pyrotechnic 'performance', which was the primary social and symbolic significance of these ceramic assemblages (Vandiver et al. 1989). It has also been noted that a relatively large proportion of the wellfired pieces were "kneaded, compressed, deformed and punctured' already during modelling while the clay paste was still soft and easily reworked if a mistake is made. They were not - and perhaps it was not the intention to make - well-formed figurines (Králík 2011.243). In contrast, no fragmentation was found of ivory objects or stone figurines.

While ceramic pellets and cones were identified at almost all Pavlovian settlements, even at small camps, figurine distribution was limited to the sites at Dolní Věstonice I - Pavlov I, Petřkovice, Předmostí and Krems-Wachtberg (Svoboda et al. 2015). The two lar- anthropomorphic figurines to impart structural stability. The number of joints, which can be weak points vulnerable to breakage, is thus minimised. In contrast, the lack of compressed limbs at the Pavlov I site might support the notion of pyrotechnic 'performance', and the intentional fragmentation and destruction of figurines. These different techniques of making ceramic figurines at two neighbouring sites show not only 'distinct styles of finished figurines', but also mark 'differences in social and embodied practice and knowledge'.

Farbstein $(2011.133-134,143)$ also observed that a carving (distinct from engraving) technique of surface incision in ivory art was broadly adopted at Pavlov I site, but was almost absent from Dolní Věstonice I. Neither technique, on the other hand, was commonly applied to ceramic figurines. All these suggest that the Pavlovian hunter-gatherers did not follow the same chaîne opératoire in designing different materials (i.e. ivory, bone, and stone). We may assume that the introduction of a new 'soft' medium was not merely the result of 'cross-craft interactions' that became objectified in the production of clay figurine and invention of pyrotechnology.

The analytical focus has recently shifted from ceramic figurines to ceramic 'pellets'. They were considered hitherto as debitage or waste. Some were interpreted as animal legs or 'limb fragments' that broke off from a larger figurine during the intentional pyrotechnic performance of fragmentation. Indeed, some preserve breaks or joints (Farbstein, Davies 2015.338). Many others were made in the form of cones or cylinders; the cones have oval or flat bases, with imprints on some (Králik 2011.217-218, 323, 243).

Rebecca Farbstein and William Davies (2015.338) that the parallel production of pellets and cones gest assemblages are from the Dolní Věstonice I and Pavlov I settlement cluster (Figs. $5,6)$.

Figurines were made from several small pieces of clay joined together, with heads, limbs, ears and tails shaped separately and then attached to the bodies (Sofer, Vandiver 1997.383-401). Rebecca Farbstein (2013. $28-31)$ recently identified different techniques at two neighbouring sites, which she terms 'techno-stylistic traits'. At Dolní Věstonice I, the limbs are 'repeatedly consolidated or compressed' on zoomorphic and

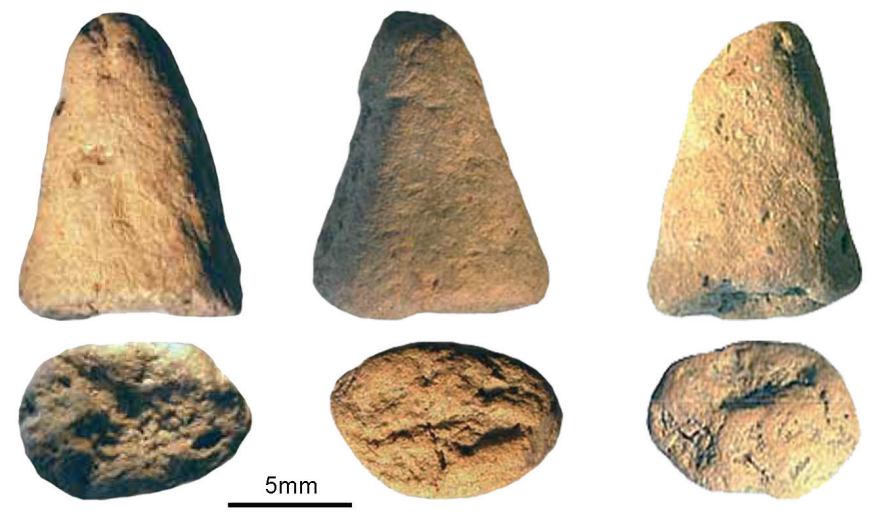

Fig. 5. Upper Paleolithic Gravettian (Pavlovian) ceramic cones from Pavlov VI (adopted from Králík 2011.Figs. 6, 13, 36). 
reveals 'technical flexibility and experimentation in chaîne opératoire' that can be ascribed to 'other social meanings', while Miroslav Králík (2011.244) suggested that cones with imprints on their bases are not figurine fragments, but 'final objects' that bear 'meanings'.

What are the 'social meanings' of figurines and cones? In the much later Pre-Pottery Neolithic in the Near East, the 'meaning' of similar ceramic figurines and identical cones (known as geometric figurines) has been contextualised within social and economic frameworks, and the identity of the body. Ian Kuijt and Meredith Chesson (2004; 2007) identified a shift in figural representation from naturalistic anthropomorphic images to geometric shapes in the period $11500-8500 \mathrm{cal} \mathrm{BP}$. They suggested that the transition from naturalistic to geometric images correlates with pressures on community subsistence and social structures. Large and densely populated communities 'struggled with the stresses of overcrowding, sufficient food production and resource depletion around settlements' at the end of the Pre-Pottery period. A new system of ownership, and greater emphasis on the household as a social and economic unit appeared, and because of 'social, economic, and shifts in public and private ritual, people no longer created and employed 'anthropological imagery in significant quantities, and never again produced naturalistic images that were tightly focused on the face and the person' (Kuijt, Chesson 2007. 226-227). Perhaps during periods when social, economic, and ritual practices were in contention, and the development of storage technologies, the surplus economy and social differentiation began, 'geometric figurines' were involved in the process of storing, counting and reproduction of goods. Denise Schmandt-Besserat (1992.168-170) suggested that they probably served as counters to measure cereals and, as mnemonic devices to store information. They have been found at Mureybet III and Cheikh Hassan, embedded in rectangular granary silos, where they have been identified as tokens.

However, by the end of the Pavlovian, $c .27000 \mathrm{cal}$ $\mathrm{BC}$, ceramic technology disappeared, with no iterations of this technology during the later Gravettian in Central Europe.

Pyrotechnology and ceramic figurines appeared again in North Africa, where at the cave of Tamar Hat (Algeria) a figurine of a wild 'Barbary Sheep' was found. It was dated with a single date in the period 22 486$21250 \mathrm{cal} \mathrm{BC}$ (68.2\%) (Saxon 1976; Bougard 2003).

A millennia later, they appeared in the central Mediterranean. Ceramic technology was independently invented at $15338-15047 \mathrm{cal} \mathrm{BC}(68.2 \%)$ at Vela Spila (on Korčula island) in the Adriatic, and subsequently lost from the socio-technical tradition at this site about two thousand years later at 13329 12985 cal BC (Farbstein et al. 2012). The thirty-six ceramic figurines and fragments from Vela Spila are the first evidence of an artistic and ceramic technology tradition in Europe after the Last Glacial Maximum.

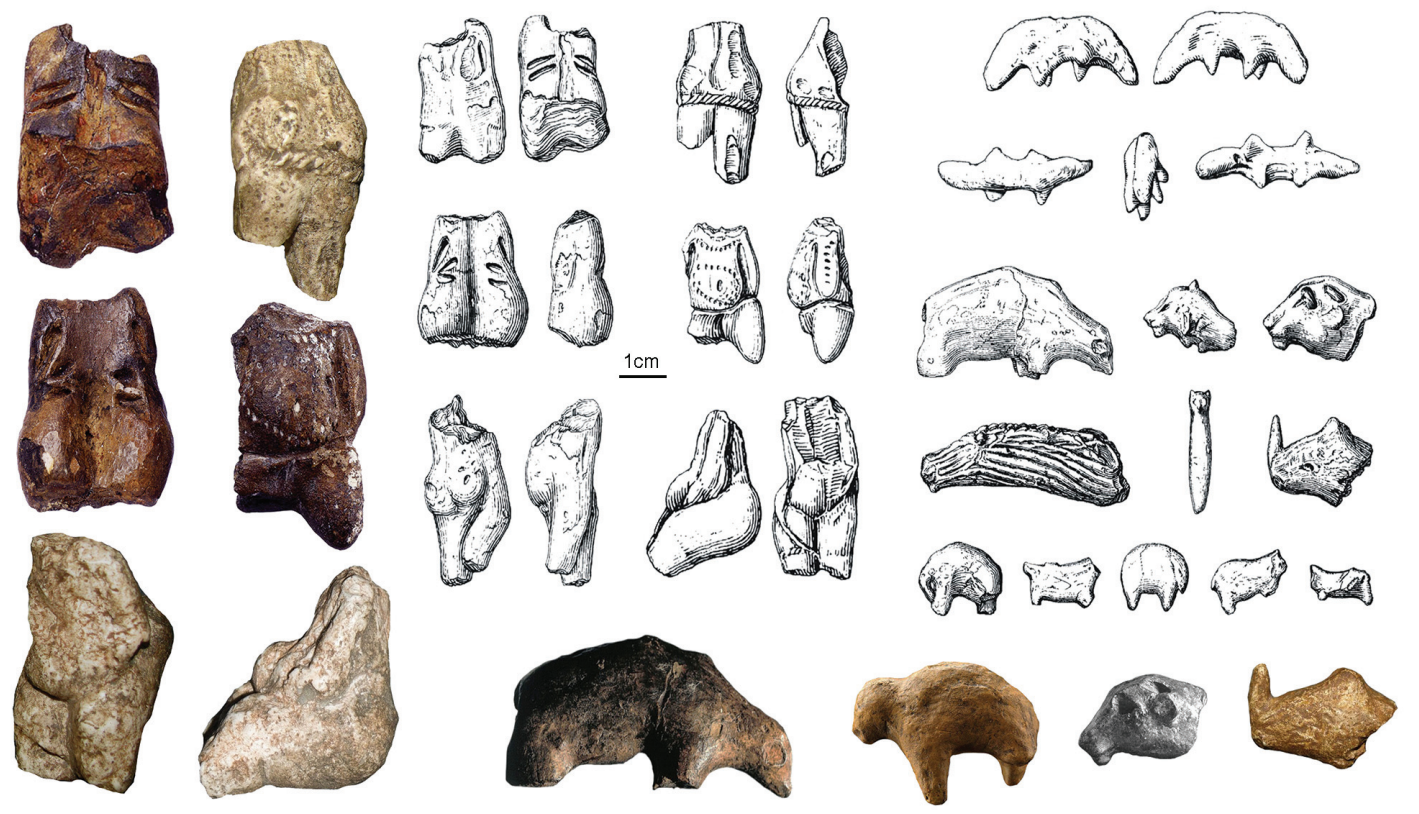

Fig. 6. Anthropomorphic and zoomorphic ceramic figurines from the Upper Palaeolithic Gravettian (Pavlovian) sites Dolní Věstonice, Pavlov and Předmosti (from Verpoorte 2001.Figs. 3. 6, 7, 8, 9, 46, 3.73, 8.1, 54). 
Pyrotechnology was again used to make art rather than functional ceramic containers. Interestingly, neither ceramic nor figurative art is known from contemporaneous sites (Kopačina, Badanj, Crvena Stijena) in the Balkans, suggesting this combined technological innovation and symbolic expression was not shared across the region. Klisoura cave in the Peloponnese is the only site at which evidence of pyrotechnology has been found. Rebecca Farbstein (2013.33-34) hypothesised that ceramic innovation did not spread across the social landscape "because the artefacts did not move throughout the landscape with these people during seasonal migrations", or perhaps "groups may not have appropriated this technology, even if they were exposed to it, because it held no social value or significance in their culturally distinct society".

An almost parallel appearance of ceramic technology was documented more than $7000 \mathrm{~km}$ to the East at the Mainninskaya site, on the Yenisei River in Western Siberia at 18 213-17 $769 \mathrm{cal} \mathrm{BC} \mathrm{(68.2 \% )} \mathrm{(Hommel}$ 2014.666) (Fig. 7).

\section{Ceramic figurines and vessels first met in the Pre-Pottery Neolithic in the Near East}

Ceramic figurine making and vessel production first appeared together in the Pre-Pottery Neolithic in Near East. They were both hypothesised as marking the beginning of the 'Age of Clay' and the advent of 'house societies', because of clay and soil, a 'material and substance that humans became thoroughly dependent on' from the Pre-Pottery Neolithic onwards (Stevanović 1997; Hodder 2011.165). Clay and soil are both building materials and substances which enable house construction, hearth and oven structures, plastered skull modelling, figurines and vessel making on the one hand, and agriculture on the other (Boivin 2008).

Only a few ceramic anthropomorphic figurines are known from the Pre-Pottery Neolithic, found at Netiv Hagdud, Dhra' and el-Khiam. They are all stylised representations of portions the human body, or of an entire body, and each involves a unique combination of marked features or omissions. Ian Kuijt and Meredith Chesson $(2004 ; 2007)$ suggested that the focus at first was on the stylised human body, mainly the lower. Later, in the PPNB, the focus shifted to 'personhood', which they believe was characterised by realistic representations of human faces. In this period, along with small figurines, many new forms of anthropomorphic ceramic representation appeared, such as full-body anthropomorphic statues, large busts with painted faces, face masks and plastered skulls. The shift in focus correlates with the appearance of large agricultural villages and rectangular residential buildings, and domesticated plants and animals on the one hand, and on the other, it relates to the recognition of the individuality of the deceased, to the idealisation of a collective ancestry, and to the creation of social memories in mortuary practices. The homogeneity of practices, they suggested, "emphasizes the deconstruction or masking of individual differences and focus on collective identities" (Kuijt, Chesson 2007.224). In the late Pre-Pottery Neolithic B and C, ceramic zoomorphic figurines almost replaced anthropomorphic ones. We mentioned above that replacement corresponds to stresses on community subsistence and social structures, and the erosion of individuality and social differentiation that entered into the negotiation of everyday life.

Pottery has been recovered in very small amounts from Pre-Pottery Neolithic contexts in the Southern Levant and Upper Mesopotamia. At Kfar HaHoresh in the Southern Levant, 23 pottery sherds have been recovered ranging in date from the Early to Late PrePottery Neolithic B, c. 8750-7500 cal BC. The appearance of pottery was not an isolated event, but a repeated or intermittent practice, since the pottery fragments were embedded within a time span of more than a millennium. Pottery making was probably very limited, for short-term personal use or for use by distinctive individuals or in certain contexts for very limited purposes (Biton et al. 2014).

The earliest pots at Tell Sabi Abyad in Upper Mesopotamia 'were shaped and finished carefully'. They have regular wall profiles and rims, and an even wall thickness. The vessels were intensively smoothed and burnished, occasionally resulting in somewhat glossy surfaces. Some were decorated with red slip and painting. They may suggest 'prestige' pottery production. Undecorated containers with a more utilitarian function, such as storage or cooking, rapidly replaced them (Nieuwenhuyse et al. 2010).

The use of pottery in Southwest Asia became widespread at the start of the Late (or Pottery) Neolithic, around or shortly before $7000 \mathrm{cal} \mathrm{BC}$. Lipid residue analyses show that vessels became associated with extensive meat (ovicaprids) exploitation during the Early Pottery period, but that this shifted towards the mixed exploitation of meat and milk (Nieuwenhuyse et al. 2015). 


\section{Epiloque}

We have emphasised that current evidence clearly shows different, but parallel, trajectories of ceramic (pyro)technology adoption and the production of fired clay items, both of which began in the Upper Palaeolithic. In the west, the focus was on figurines and cones in the Palaeolithic, followed by vessels production in the Neolithic. In the east, the focus was on vessel making from the outset. The western tradition predates the eastern by about eleven millennia. While pellets, cones and figurines first appeared in Central Europe at $c .31000 \mathrm{cal} \mathrm{BC}$, the earliest vessels in Xianrendong Cave are dated to c. 20000 cal BC (Fig. 7).

It is unlikely that any single model will ever reveal where ceramic (pyro)technology first appeared or how fast it spread or diffused from hypothesised 'centres of innovation'. The first pottery making in East Asia was confined to a small number of sites, and persisted in episodic, low-scale usage until the Early Holocene.

Residual analyses show that early pottery in East Asia was used for food preparation and perhaps for storage tasks, but small amounts of pottery found at the earliest sites suggest that it may not have been used extensively for everyday activities. It is unlike- ly it was used to intensify wild seed exploitation, and/or left as 'caching pots' out in the fields. We may hypothesise that it might have marked incipient forms of privatisation, and may have been used as prestigious containers of luxury foods (e.g., fish oils).

We may also hypothesise that the appearance of ceramics probably related to 'cross-craft interactions', such as the lining of organic baskets, but this does not explain why some of the earlier uses of ceramic (pyro)technology in the European Palaeolithic did not lead to the same innovation. However, the widespread and twenty-millennia-long episodic trajectory of the fired clay figurine tradition in western Eurasia did not lead to the invention of ceramic container technologies. Recalling arguments about chaîne opératoire techniques, these data may suggest the 'embedded nature' of technological choices and social and ideological practices to which ceramic inventions and innovations were related (see the concept of 'embedded technologies' in Sillar, Tite 2000). The makers of Gravettian figurines may have created 'social boundaries' by not sharing all of the same series of technical gestures or related social behaviours, and the intentional fragmentation and destruction of figurines may suggest that the female body did not provide metaphors of 'containing' before the Neolithic.

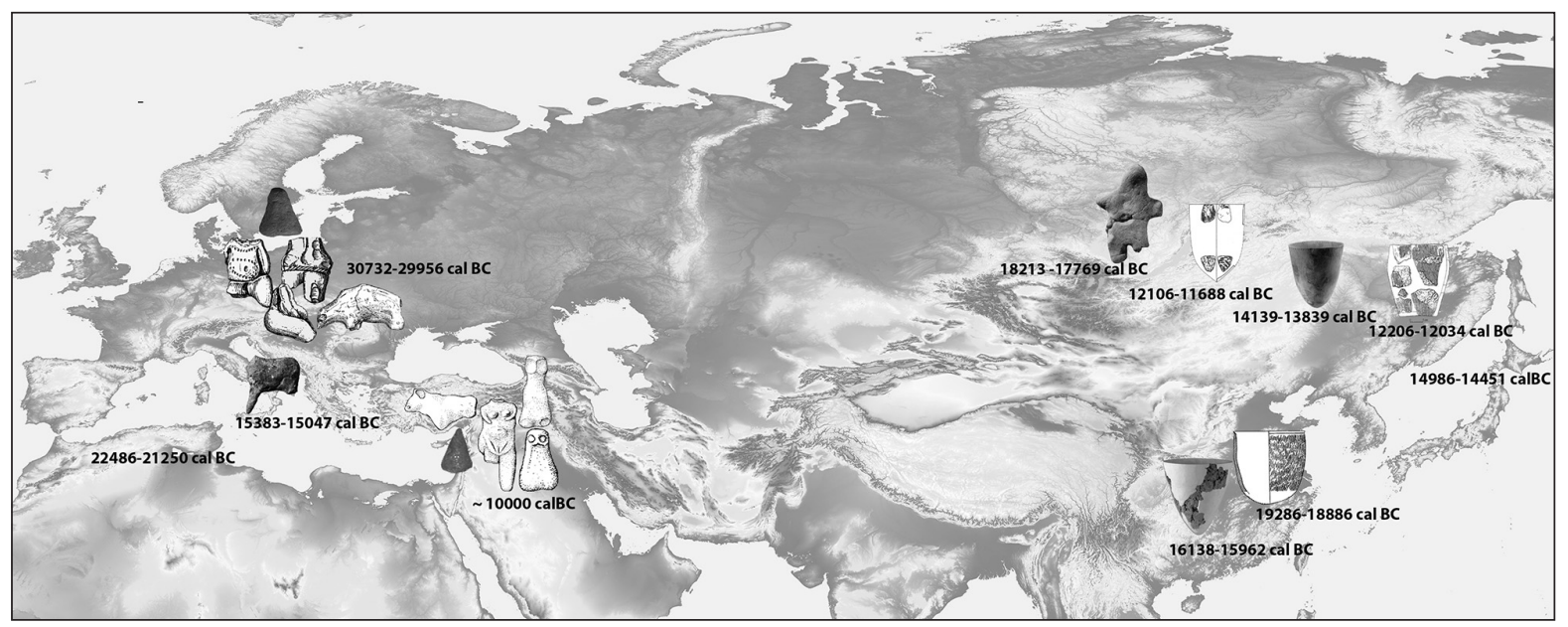

Fig. 7. Parallel trajectories of ceramic technology adoption and burnt clay items making that both started in Upper Palaeolithic. The western focused on figurines and cones making in Palaeolithic, followed by vessels producing in Neolithic. The eastern focused on vessels making from the very beginning. Radiocarbon dates relate to the earliest appearance of ceramic (pyro)technology at Dolní Vèstonice, Pavlov, Petřkovice, Předmostí in Moravia, and Krems-Wachtberg sites in Austria (Svoboda et al. 2015.202,Tab. 1; 2014.76; see also Verpoorte 2001.86; Einwögerer, Simon 2008.42); Tamar Hat in Algeria (Bougard 2003. 32); Mä̈ninskaya site, on the Yenisei River bank in Siberia in Russia (Hommel 2014.666); Vela Spila in Croatia (Farbstein et al. 2012.3-5); Xianrendong Cave and Yunchayan cave in China Wu et al. 2012. 1699, Tab. 2; Boaretto et al. 2009.9596, Tab. 3); Odai Yamamoto in Japan (Kuzmin 2015.Tab. 1); Khummi, Ust Karenga and Studenoe in Eastern Siberia and Rusussian Far East (Kuzmin 2015.Tab. 1). The radiocarbon dates are calibrated with $0 x$ Cal $v$ 4.2.4 at $68.2 \%$ probability. 
The 'body language' of technical gestures and skills employed to make ceramic figurines may have also been a 'form of silent discourse' with which gendered identity and status were negotiated (Dobres, Hoffman 1994; Dobres 2010). However, the intentional breaking of ceramic figurines may have mediated relationships between the members of society (see above, Chapman 2000a), but also acted as a symbolic break in social alliances (Dobres 2010.109).

In the western ceramic (pyro)technology trajectory, the earliest, 'prestige', pottery making appeared at $8750-7500$ cal BC. This was quickly replaced by thick, undecorated, organic tempered vessels that were rather 'entangled' in contexts of domestic food production, processing and storage, separated from the entanglement surroundings of 'wild animals, death and burial' (see the concept of 'entanglement' in Hodder 2012).
We may hypothesise in conclusion that the (pre)history of ceramic use in Eurasia relates to neither the Neolithic revolution nor diffusion from a Palaeolithic pottery centre in East Asia, but to two parallel and very long trajectories of episodic ceramic technology use in pre-Neolithic hunter-gatherer societies. In the eastern, Asian ceramic trajectory, pottery was produced from the beginning. The human body was probably not the 'schemata' that marked both containment and the perception of pots as 'bounded objects' (i.e. containers) in Asian hunter-gatherer societies. Ceramic figurines, cones and pellets mark the western, European trajectory for the first twentytwo thousand years. Pottery appeared together with domestic food production. However, in East European hunter-gatherer societies, the domestic mode of food production was not the cultural choice.

\section{References}

Arnold D. E. 1985. Ceramic Theory and Cultural Process. Cambridge University Press. Cambridge

Atalay S. 2005. Domesticating clay: the role of clay balls, mini balls and geometric objects in daily life at Çatalhöyük. In I. Hodder (ed.), Changing Materialities at Catalhöyük: Reports from the 1995-99 Seasons. McDonald Institute for Archaeological Research. British Institute of Archaeology at Ankara Monograph. Cambridge: 139-168.

Barley N. 1994. Smashing Pots. Works of Clay from Africa. Smithsonian Institution Press. Washington D.C.

Benz M. 2015. Feasting - Ein vielschichtiges Konzept und dennoch kein Passepartout. Gedanken zu B. Haydens "The Power of Feasts". Germania 93: 225-232.

Bettinger R. L., Barton L. and Morgan C. 2010. The Origins of Food Production in North China: A Different Kind of Agricultural Revolution. Evolutionary Anthropology 19: 9-21.

Berkes F., Colding J. and Folke C. 2003. Introduction. In F. Berkes, J. Colding and C. Folke (eds.), Navigating SocialEcological Systems. Building Resilience for Complexity and Change. Cambridge University Press. Cambridge: 1-30.

Bird D. W., O'Connell J. F. 2006. Behavioral Ecology and Archaeology. Journal of Archaeological Research 14: 143-188.

Biton R., Goren Y. and Goring-Morris A. N. 2014. Ceramics in the Levantine Pre-Pottery Neolithic B: evidence from
Kfar HaHoresh, Israel. Journal of Archaeological Science 41: $740-748$

Boaretto E. and 12 co-authors. 2009. Radiocarbon Dating of Charcoal and Bone Collagen Associated with Early Pottery at Yuchanyan Cave, Hunan Province, China. Proceedings of the National Academy of Sciences USA 106(24): 9595-9600.

Boivin N. 2004. From veneration to exploitation. Human engagement with the mineral world. In N. Boivin, M.- A. Owoc (eds.), Soil, Stones and Symbols: Cultural Perceptions of the Mineral World. University College London Press. London: 1-30.

Bourdieu P. 1984. Distinction. A Social Critique of Taste. Harvard University Press. Cambridge.

Bougard E. 2003. Ceramic in the Upper Palaeolithic. In A. Gibson (ed.), Prehistoric pottery: people pattern and purpose. Prehistoric ceramics research group. Occasional publication 4. British Archaeological Reports IS 1156. Archaeopress. Oxford: 429-434.

Bowles S., Choi J.-K. 2013 Coevolution of farming and private property during the early Holocene. Proceedings of the National Academy of Sciences USA 110(22): 88308835 .

Braithwaite M. 1982. Decoration as ritual symbol: a theoretical proposal and an ethnographic study in southern Sudan. In I. Hodder (ed.), Symbolic and structural archaeology. Cambridge University Press. Cambridge: 80-88. 
Brown J. A. 1989. The beginnings of pottery as an economic process. In S. E. van der Leeuw, R. Torrence (eds.), What's New? A Closer Look at the Process of Innovation. Unwin Hyman. London: 203-224.

Brück J. 2006. Death, Exchange and Reproduction in the British Bronze Age. European Journal of Archaeology 9(1): 73-101.

Budja M. 2012. Interpretative trajectories toward understanding personhoods in prehistory. Documenta Praehistorica 39: 137-153.

Chapman J. 2000a. Fragmentation in Archaeology. People, places and broken objects in the prehistory of southeastern Europe. Routledge. London, New York.

2000b. Tensions at Funerals. Micro-Transition Analysis in Later Hungarian Prehistory. Archaeolingua, Series Minor. Budapest.

2008. Object fragmentation and past landscapes. In B. David, J. Thomas (eds.), Handbook of Landscape Archaeology. Left Coast Press, Walnut Creek, CA: 187-201.

Chapman J., Gaydarska B. 2007. Parts and Wholes. Fragmentation in Prehistoric Context. Oxbow Books. Oxford.

Childe V. G. 1958. Man makes himself. The New American Library of World Literature, Inc. New York.

Codding B. F., Bird D. W. 2015. Behavioral ecology and the future of archaeological science. Journal of Archaeological Science 56: 9-20.

Cohen D. J. 2013. The Advent and Spread of Early Pottery in East Asia: New Dates and New Considerations for the World's Earliest Ceramic Vessels. Journal of Austronesian Studies 4(2): 55-92.

Craig O. E., Steele V. J., Fischer A., Hartz S., Andersen S. H., Donohoe P., Glykou A., Saul H., Jones D. M., Koch E. and Heron C. P. 2011. Ancient lipids reveal continuity in culinary practices across the transition to agriculture in Northern Europe. Proceedings of the National Academy of Sciences USA 108(44): 17910-17915.

Craig 0. E. and 13 co-authors. 2013. Earliest evidence for the use of pottery. Nature 496: 351-454.

Crown P. L., Wills W. H. 1995a. The origins of Southwestern ceramic containers: women's time allocation and economic intensification. Journal of Anthropological Research 51: 173-186.

1995b. Economic intensification and the emergence of ceramic containers in the American Southwest. In W. K. Barnett, J. W. Hoopes (eds.), The Emergence of Pottery: Technology and Innovation in Ancient Societies.
Smithsonian Institution Press. Washington D.C.: $241-$ 254.

David N., Sterner J. and Gavua K. 1988. Why Pots are Decorated? Current Anthropology 29(3): 365-389.

Diehl M. W., Waters J. A. 2006. Aspects of optimization and risk during the Early Agricultural Period in Southeastern Arizona. In D. J. Kennett, B. Winterhalder (eds.), Behavioral Ecology and the Transition to Agriculture. University of California Press. Berkeley: 63-86.

Dobres M.-A. 2010. Archaeologies of technology. Cambridge Journal of Economics 34: 103-114.

Dobres M.-A., Hoffman R. C. 1994. Social Agency and the Dynamics of Prehistoric. Journal of Archaeological Method and Theory 1(3): 211-258.

Durkheim E. 2005. Suicide. A study in sociology. Routledge. London, New York.

Eckert S. L. 2014. Ceramic in Pre-Hispanic North America. In H. Selin (ed.), Encyclopaedia of the History of Science, Technology, and Medicine in Non-Western Cultures. Springer Netherlands. Dordrecht: 515-522.

Eerkens J. W. 2003. Residential Mobility and Pottery Use in the Western Great Basin. Current Anthropology 44(5): 728-738.

2004. Privatization, Small-Seed Intensification, and the Origins of Pottery in the Western Great Basin. American Antiquity 69(4): 653-670.

2008. Nomadic Potters. Relationships between Ceramic Technologies and Mobility Strategies. In H. Barnard, W. Wendrich (eds.), The Archaeology of Mobility: Old World and New World Nomadism. Cotsen Institute of Archaeology. Los Angeles: 307-326.

Eerkens J. W., Neff H. and Glascock M. D. 2002. Ceramic Production among Small-Scale and Mobile Hunters and Gatherers: A Case Study from the Southwestern Great Basin. Journal of Anthropological Archaeology 21: 200-229.

Eerkens J. W., Lipo C. P. 2014. A tale of two technologies: Prehistoric diffusion of pottery innovations among hunter-gatherers. Journal of Anthropological Archaeology 35: 23-31.

Einwögerer T., Simon U. 2008. Die Gravettienfundstelle Krems-Wachtberg. Archäologie Österreichs 19(1): 3842.

Farbstein R. 2011. The Significance of Social Gestures and Technologies of Embellishment in Paleolithic Portable Art. Journal of Archaeological Method and Theory 18: 125146. 
2013. Making art, making society: the social significance of small-scale innovations and experimentation in $\mathrm{Pa}$ laeolithic portable art. World Art 3(1): 23-39.

Farbstein R., Radić D., Brajković D. and Miracle P. T. 2012. First Epigravettian Ceramic Figurines from Europe (Vela Spila, Croatia). PLoS ONE 7(7): e41437.

Farbstein A. R., Davies W. 2015. Rediscovering Paleolithic art: overlooked ceramic figurines from the Pavlovian. In S. Sázelová, M. Novák and A. Mizerová (eds.), Forgotten times and spaces: New perspectives in paleoanthropological, paleoetnological and archeological studies. Institute of Archeology of the Czech Academy of Sciences. Masaryk University. Brno: 328-339.

Fitzhugh B. 2001. Risk and invention in human technological evolution. Journal of Anthropological Archaeology 20: $125-167$.

Fowler C. 2001. Personhood and social relations in the British Neolithic with a study from the Isle of Man. Jour nal of Material Culture 6(2): 137-163.

2004. The Archaeology of Personhood. An anthropological approach. Routledge. London, New York.

Frieman C. J. 2013. Innovation and Identity. The Language and Reality of Prehistoric Imitation and Technological Change. In J. J. Card (ed.), Hybrid Material Culture. The Archaeology of Syncretism and Ethnogenesis. Center for Archaeological Investigations. Carbondale: 318-341.

Gamble C. 2007. Origins and Revolutions. Human Identity in Earliest Prehistory. Cambridge University Press. Cambridge.

Garraty C. P. 2011. The origins of pottery as a practical domestic technology: Evidence from the middle Queen Creek area, Arizona. Journal of Anthropological Archaeology 30: 220-234.

Gell A. 1998. Art and Agency. Clarendon. Oxford.

Gibbs K. 2012. Not meant to last: mobility and disposable pottery. Documenta Praehistorica 39: 83-93.

2015. Pottery Invention and Innovation in East Asia and the Near East. Cambridge Archaeological Journal 25(1): 339-351.

Gibbs K., Jordan P. 2013. Bridging the Boreal Forest Siberian Archaeology and the Emergence of Pottery among Prehistoric Hunter-Gatherers of Northern Eurasia. Sibirica 12(1): 1-38

2016. A comparative perspective on the 'western' and 'eastern' Neolithics of Eurasia: Ceramics; agriculture and sedentism. Quaternary International 419: 27-35.
Gimbutas M. 1989.The Language of the Goddess. Thames and Hudson. London.

Gibson J. J. 1979. The Ecological Approach to Perception. Houghton Mifflin. London.

Haaland R. 2009. Aquatic Resource Utilization and the Emergence of Pottery during the Late Palaeolithic and Mesolithic: A Global Perspective from the Nile to China. In T. Oestigaard (ed.), Water, Culture and Identity: Comparing Past and Present Traditions in the Nile Basin Region. University of Bergen. BRIC Press. Bergen: 213-235.

Halstead P. 2012. Feast, food and fodder in NeolithicBronze age Greece: commensality and the construction of value. eTopoi. Journal for Ancient Studies 2: 21-51.

Händel M., Simon U., Einwögerer T. and Neugebauer-Maresch C. 2009. New excavations at Krems-Wachtberg - approaching a well-preserved Gravettian settlement site in the middle Danube region. Quartär 56: 187-196.

Haraway D. 2003. The Companion Species Manifesto: Dogs, People and Significant Otherness. Prickly Paradigm. Chicago.

Hayden B. D. 1990. Nimrods, piscators, pluckers, and planters: the emergence of food production. Journal of Anthropological Archaeology 9: 31-69.

1995. Pathways to Power. Principles for Creating Socioeconomic Inequalities. In T. D. Price, G. M. Feinman (eds.), Foundations of Social Inequality. Plenum Press. New York: 15-86.

1996. Feasting in prehistoric and traditional societies. In P. Wiessner, W. Schiefenhövel (eds.), Food and the Status Quest: An Interdisciplinary Perspective. Anthropology of Food \& Nutrition Providence Vol. 1. Berghahn Books. Providence: 127-147.

1998. Practical and prestige technologies: the evolution of material systems. Journal of Archaeological Method and Theory 5: 1-55.

2001. Fabulous Feasts. A Prolegomenon to the Importance of Feasting. In M. Dietler, B. Hayden (eds.), Feasts. Archaeological and Ethnographic Pespectives on Food, Politics, and Power. The University of Alabama Press. Alabama: 23-64.

2003. Were luxury foods the first domesticates? Ethnoarchaeological perspectives from Southeast Asia. World Archaeology 34(3): 458-469.

2009. Funerals As Feasts: Why Are They So Important? Cambridge Archaeological Journal 19(1): 29-52.

2011. Big Man, Big Heart? The Political Role of Aggrandizers in Egalitarian and Transegalitarian Societies. In 
D. Forsyth, C. Hoyt (eds.), For the Greater Good of All. Perspectives on Individualism, Society, and Leadership. Palgrave Macmillan. New York: 101-118.

2014. The Power of Feasts. From Prehistory to Present. Cambridge University Press. Cambridge.

Heidegger M. 1971. Poetry, Language, Thought. Harper Collins Publishers Inc. New York.

Heidke J. M. 2005. Early Agricultural Period Pottery from Las Capas and Los Pozos. In R. J. Sliva (ed.), Material Cultures and Lifeways of Early Agricultural Communities in Southern Arizona. Anthropological Papers No. 35. Center for Desert Archaeology. Tucson: 171-206.

2006. Native American pottery. In J. H. Thiel, J. B. Mabry (eds.), Rio Nuevo Archaeology Program, 20002003: Investigations at the San Agustin Mission and Mission Gardens, Tucson Presidio, Tucson Pressed Brick Company, and Clearwater Site. Technical Series No. 2004-11. Center for Desert Archaeology. Tucson: 7.1-7.93.

Heidke J. M., Stark M.T. 2002. Early ceramics in southeastern Arizona: technology, iconography, and function. In R. Harrison, Gillespie M. and Peurumaki-Brown M. (eds.), Eureka: The Archaeology of Innovation and Science. Proceedings of the 29th Annual Chacmool Conference. Archaeological Association of the University of Calgary. Calgary: 345-356.

Hodder I. 1988. Comments. Current Anthropology 29(3): 382-383.

2011. Human-thing entanglement: towards an integrated archaeological perspective. Journal of the Royal Anthropological Institute (N.S.) 17: 154-177.

2012. Entangled. An Archaeology of the Relationships between Humans and Things. Willey-Blackwell. Malden, Oxford, Chichester.

Hommel P. 2014. Ceramic Technology. In V. Cummings, P. Jordan and M. Zvelebil (eds.), The Oxford Handbook of the Archaeology and Anthropology of Hunter-Gatherers. Oxford University Press. Oxford: 663-692.

Huckell L. W. 2006. Ancient Maize in the American Southwest What Does It Look Like and What Can It Tell Us? In J. E. Staller, R. H. Tykot and B. F. Benz (eds.), Histories of Maize. Multidisciplinary Approaches to the Prehistory, Biogeography, Domestication, and Evolution of Maize. Elsevier/Academic Press. Amsterdam: 97-107.

Hutchby I. 2001. Technologies, Texts and Affordances. Sociology 35(2): 441-456.
Ikawa-Smith F. 1976. On ceramic technology in east Asia. Current Anthropology 17: 513-515.

Ingold T. 1983. The Significance of Storage in Hunting Societies. Man 18(3): 553-571.

2000. The Perception of the Environment: Essays on Livelihood, Dwelling and Skill. Routledge. London.

2006. Rethinking the animate, re-animating thought. Ethnos 71(1): 9-20.

2007. Materials against materiality. Archaeological Dialogues 14: 1-38.

Johnson M. L. 1987. The Body in the Mind: The Bodily Basis of Meaning, Imagination and Reason. University of Chicago Press. Chicago.

Jordan P., Zvelebil M. 2009. Ex Oriente Lux: The Prehistory of Hunter-Gatherer Ceramic Dispersals. In P. Jordan, M. Zvelebil (eds.), Ceramics before Farming: The Dispersal of Pottery among Prehistoric Eurasian Hunter-Gatherers. Left Coast Press. Walnut Creek: 33-89.

Jordan P., Gibbs K., Hommel P., Piezonka H., Silva F. and Steele J. 2016. Modelling the diffusion of pottery technologies across Afro-Eurasia: emerging insights and future research. Antiquity 90(351): 590-603.

Kalicz N. 1980. Götter aus Ton. Das Neolithikum und die Kupferzeit in Ungarn. Hereditas. Corvina Kiadó. Budapest.

Kaneko M. 2007. Variations in Pottery Making by Ari Potters in Southwestern Ethiopia: Analysis of the Finger Movement Patterns Using in Forming Pots. Nilo-Ethiopian Studies 11: 1-15.

2009. Variations in Pottery Making in Southwestern Ethiopia. In S. Ege , H. Aspen, B. Teferra and S. Bekele (eds.), Proceedings of the $16^{\text {th }}$ International Conference of Ethiopian Studies. Vol. 2. Department of Social Anthropology. Norwegian University of Science and Technology. Trondheim: 383-394.

Keally, Taniguchi Y. and Kuzmin V. Y. 2003. Understanding the beginnings of pottery technology in Japan and neighbouring East Asia. The Review of Archaeology 24(2): 3-14.

Knappett C. 2004. The Affordances of Things: a Post-Gibsonian Perspective on the Relationality of Mind and Matter. In E. DeMarrais, C. Gosden and C. Renfrew (eds.), Rethinking Materiality: The Engagement of Mind with the Material World. McDonald Institute Monographs. McDonald Institute for Archaeological Research. Cambridge: $43-51$. 
2005. Thinking Through Material Culture. An Interdisciplinary Perspective. Archaeology, Culture, and Society. University of Pennsylvania Press. Philadelphia.

Knappett C., Malafouris L. 2008. Material and Nonhuman Agency: An Introduction. In C. Knappett, L. Malafouris (eds.), Material Agency. Towards a Non-Anthropocentric Approach. Springer. New York: ix-xix.

Knappett C., Malafouris L. and Tomkins P. 2010. Ceramics (as containers). In M. C. Beaudry, D. Hick (eds.), The Oxford Handbook of Material Culture Studies. Oxford Handbooks in Archaeology. Oxford University Press. 0xford: 588-612.

Králík M. 2011. Ancient Ceramics and Imprints on their Surfaces. In J. Svoboda (ed.), Pavlov - Excavations 2007 - 2011. Dolnověstonické studie 18. Academy of Sciences of the Czech Republic. Brno: 207-244.

Králík M., Einwögerer T. 2010. Imprints discovered on Paleolithic ceramics from Krems-Wachtberg and KremsHundssteig sites, Lower Austria. In C. Neugebauer-Maresch, L. Owen (eds.), New aspects of the Central and Eastern European Upper Palaeolithic. Methods, Chronology, Technology, and Subsistence. Mitteilungen der Prähistorischen Kommission 72. Österreichische Akademie der Wissenschaften. Vienna: 255-272.

Kuijt I., Chesson M. 2004. Lumps of Clay and Pieces of Stone: Ambiguity, Bodies, and Identity as Portrayed in Neolithic Figurines. In R. Bernbeck, S. Pollock (eds.), Archaeologies of the Near East. Critical Perspectives. Basil Blackwell. London: 152-183.

2007. Imagery and Social Relationships. Shifting Identity and Ambiguity in the Neolithic. In C. Renfrew, I. Morley (eds.), Image and Imagination. A Global Prehistory of Figurative Representation. McDonald Institute Monographs. Cambridge: 211-226.

Kuzmin Y. V. 2015. The origins of pottery in East Asia: updated analysis (the 2015 state-of-the-art). Documenta Praehistorica 42: 1-11.

Lakoff G. 1987. Women, Fire, and Dangerous Things: what categories reveal about the mind. University of Chicago Press. Chicago.

Lakoff G., Johnson M. L. 1980. Metaphors We Live By. University of Chicago Press. Chicago.

1999. Philosophy in the Flesh: the Embodied Mind and its Challenge to Western Thought. Basic Books. New York.

Latour B.1992. Where are the missing masses? The sociology of a few mundane artifacts. In W. E. Bijker, J. Law (eds.), Shaping Technology/Building Society. Inside Technology. The MIT Press. Cambridge, Mass.: 151-180.

Lévi-Strauss C. 1988. The Jealous Potter. University of Chicago Press. Chicago.

Lienhard J. H. 2006. How Invention Begins. Echoes of Old Voices in the Rise of New Machines. Oxford University Press. Oxford.

Liu L., Bestel S., Shi J., Song Y. and Chen X. 2013. Paleolithic human exploitation of plant foods during the last glacial maximum in North China. Proceedings of the $\mathrm{Na}$ tional Academy of Sciences USA 110(14): 5380-5385.

Longacre W. A. 1995. Why Did They Invent Pottery Anyway? In W. K. Barnett, J. W. Hoopes (eds.), The Emergence of Pottery: Technology and Innovation in Ancient Societies. Smithsonian Institution Press. Washington D.C.: 277-280.

Lu T. L.-D. 2011. Early pottery in China. Asian Perspectives 49: 1-42.

Lucquin A. and 13 co-authors. 2016. Ancient lipids document continuity in the use of early hunter-gatherer pottery through 9,000 years of Japanese prehistory. Proceedings of the National Academy of Sciences USA 113 (15): 3991-3996.

Mabry J. B. 2006 Radiocarbon Dating of the Early Occupations. In J. H. Thiel, J. B. Mabry (eds.), Rio Nuevo Archaeology, 2000-2003. Investigations at the San Agustin Mission and Mission Gardens, Tucson Presidio, Tucson Pressed Brick Company, and Clearwater Site. Technical Report No. 2004-11. Desert Archaeology Inc. Tucson: 19.1-19.5.

McDonnell J. G. 2001. Pyrotechnology. In D. R. Brothwel, M. Pollard (eds.), Handbook of Archaeological Science. Wiley. London: 493-506.

Merleau-Ponty M. 2005. Phenomenology of Perception. Routledge. London, New York.

Miller H. 2007. Archaeological Approaches to Technology. Elsevier, Academic Press. London, Amsterdam.

Mlekuž D. 2007. 'Sheep are your mother': rhyta and the interspecies politics in the Neolithic of the eastern Adriatic. Documenta Praehistorica 34: 267-280.

Morris B. 2000. Animals and Ancestors. An Ethnography. Berg. Oxford, New York.

Nadasdy P. 2007. The gift in the animal: The ontology of hunting and human-animal sociality. American Ethnologist 34(1): 25-43. 
Nieuwenhuyse 0. P., Akkermans P. M. M. G. and van der Plicht J. 2010. Not so coarse, nor always plain - the earliest pottery of Syria. Antiquity 84(323): 71-85.

Nieuwenhuyse 0. P., Roffet-Salque M., Evershed R. P., Akkermans P. M. M. G. and Russell A. 2015. Tracing pottery use and the emergence of secondary product exploitation through lipid residue analysis at Late Neolithic Tell Sabi Abyad (Syria). Journal of Archaeological Science 64: 54-66.

Olsen B. 2010. In Defense of Things. Altamira Press. Walnut Creek.

Ozker D. 1982. An Early Woodland Community at the Schultz Site 20SA2 in the Saginaw Valley and the Nature of the Early Woodland Adaptation in the Great Lakes Region. Anthropological Papers No. 70. Museum of Anthropology. University of Michigan. Ann Arbor.

Pankhurst A. 2003. Dimensions and conception of marginalisation. In D. Freeman, A. Pankhurst (eds.), Peripheral People. The Excluded Minorities of Ethiopia. The Red Sea Press, Inc. Asmara: 1-27.

Perić S. 1996. Kulth-Rhytone der neolitischen Viehzüchter der Balkanhalbinsel. Starinar 47: 21-66.

Perlès C. 2001. The Early Neolithic in Greece. The first farming communities in Europe. Cambridge University Press. Cambridge.

Radivojević M. 2015. Inventing Metallurgy in Western Eurasia: a Look Through the Microscope Lens. Cambridge Archaeological Journal 25(1): 321-338.

Read D, van der Leeuw S. 2008. Biology is only part of the story. Philosophical Transactions of the Royal Society B 363: 1959-1968.

Rice P. M. 1999. On the Origins of Pottery. Journal of Archaeological Method and Theory 6(1): 1-54.

Reichel-Dolmatoff G. 1978. Desana Animal Categories, Food Restrictions, and the Concept of Color Energies. Journal of Latin American Lore 4(2): 243-291.

Reid K. C. 1984. Fire and ice: new evidence for the production and preservation of Late Archaic fiber-tempered pottery in the middle-latitude lowlands. American Antiquity 49(1): 55-76.

Roberts B. W., Radivojević M. 2015. Invention as a Process: Pyrotechnologies in Early Societies. Cambridge Archaeological Journal 25(1): 299-306.

Saxon E. C. 1976. Pre-Neolithic pottery: new evidence from North Africa. Proceedings of the Prehistoric Society 42: 327-329.
Shennan S. 1989. Cultural transmission and cultural change. In S. E. van der Leeuw, R. Torrence (eds.), What's New? A Closer Look at the Process of Innovation. Unwin Hyman. London: 330-346.

Sillar B., Tite M. S. 2000. The challenge of 'technological choices' for materials science approaches in archaeology. Archaeometry 42(1): 2-20.

Silva F., Steele J., Gibbs K. and Jordan P. 2014. Modelling spatial innovation diffusion from radiocarbon dates and regression residuals: the case of early Old World pottery. Radiocarbon 56(2): 723-732.

Skibo M. J., Schiffer B. M.1995. The Clay Cooking Pot: An Exploration of Women's Technology. In J. M. Skibo, W. H. Walker and A. E. Nielsen (eds.), Expanding Archaeology. University of Utah Press. Salt Lake City: 80-91.

Schmandt-Besserat D. 1992. Before writing Volume I. From counting to cuneiform. University of Texas Press. Austin.

Smith M. L. 2012. What it takes to get complex: food, goods, and work as shared cultural ideals from the beginning of sedentism. In M. E. Smith (ed.), The comparative archaeology of complex societies. Cambridge University Press. Cambridge: 44-61.

2015. Feasts and Their Failures. Journal of Archaeological Method and Theory 22: 1215-1237.

Smit B., Wandel J. 2006. Adaptation, adaptive capacity and vulnerability. Global Environmental Change 16(3): 282292.

Soffer O., Vandiver P., Klima B. and Svoboda J. 1993. The Pyrotechnology of Perfomance Art: Moravian Venuse and Wolverines. In H. Knecht, A. Pike-Tay and R. White (eds.), Before Lascaux. CRC Press. Boca Raton: 259-275.

Soffer 0., Vandiver P. 1997. The Ceramics from Pavlov I -1957 Excavation. In J. Svoboda, P. Škrdla (eds.), Pavlov I - Northwest (The Upper Paleolithic burial and its settlement context). The Dolni Vestonice Studies 4. Academy of Sciences of the Czech Republic. Institute of Archaeology in Brno. Masaryk University. Department of Anthropology at Faculty of Science. Brno: 383-401.

Soffer 0., Vandiver P. 2005. Ceramic fragments. In J. Svoboda( ed.), Pavlov I Southeast: A window into the Gravettian lifestyles. Academy of Sciences of the Czech Republic, Institute of Archaeology at Brno, Polish Academy of Sciences, Institute of Systematics and Evolution of Animals. Brno: 415-432.

Stark M. T. 2003. Current Issues in Ceramic Ethnoarchaeology. Journal of Archaeological Research 11(3): 193242. 
Stevanović M. 1997. The Age of Clay: the social dynamics of house destruction. Journal of Anthropological Archaeology 16: 334-395.

Svoboda J., Novák M. and Sázelová S. 2014. Early Gravettian occupations at Dolní Věstonice-Pavlov. Comments on the Gravettian origin. In S. Sázelová, A. Hupková and T. Mořkovský (eds.), Mikulov Anthropology Meeting. The Dolní Věstonice Studies 20. Academy of Sciences of the Czech Republic. Institute of Archaeology in Brno. Masaryk University. Department of Anthropology at Faculty of Science. Brno: 73-78.

Svoboda J., Hladilová Š., Ivan Horáček I., Kaiser J., Králík M., Novák J., Novák M., Pokorný P., Sázelová S., Smolíková L. and Zikmund T. 2015. Dolní Věstonice IIa: Gravettian microstratigraphy, environment, and the origin of baked clay production in Moravia. Quaternary International 359: 195-210.

Taché K., Craig 0. E. 2015. Cooperative harvesting of aquatic resources and the beginning of pottery production in north-eastern North America. Antiquity 89(343): 177-190.

Teilhet J. H. 1978. The Equivocal Role of Women Artists in Non Literate Cultures. Heresis 4(1): 96-102.

Tilley C. 1996. An Ethnography of the Neolithic. Early Prehistoric Societies in Southern Scandinavia. Cambridge University Press. Cambridge.

Twiss K. C. 2012. The archaeology of food and social diversity. Journal of Archaeological Research 20: 357-395.

van der Veen M. 2003. When is food a luxury? World Archaeology 34(3): 405-427.

Vander Linden M. M. 2001. Social Dynamics and Pottery Distribution in the Faro Department, Northern Cameroon. African Archaeological Review 18(3): 135-151.

Vandiver B. P., Soffer O., Klima B. and Svoboda J. 1989. The Origin of Ceramic Technology at Dolni Vestonice, Czechoslovakia. Science 246(4933): 1002-1008.

Verpoorte A. 2001. Places of Art, Traces of Fire. A Contextual Approach to Anthropomorphic Figurines in the Pavlovian (Central Europe, 29-24 kyr BP). Archaeological Studies Leiden University 8. Dolní Věstonice Studies 6. Leiden. Brno

Vitelli K. D. 1989. Were Pots First Made for Foods? Doubts from Franchthi. World Archaeology 21(1): 17-29.
1993. Franchthi Neolithic Pottery. Vol. 1. Classification and Ceramic Phases 1 and 2. Excavations at Franchthi Cave, Greece. Fascicle 8. Indiana University Press. Bloomington.

1995. Pots, Potters, and the Shaping of Greek Neolithic Society. In W. K. Barnett, J. W. Hoopes (eds.), The Emergence of Pottery: Technology and Innovation in Ancient Society. Smithsonian Institution Press. Washington D.C.: 55-63.

1999. "Looking Up": at Early Ceramics in Greece. In J. M. Skibo, G. M. Feinman (eds.), Pottery and People. A Dynamic Interaction. The University of Utah Press. Salt Lake City: 184-198.

Voutsaki S. 2010. Agency and personhood at the onset of the Mycenaean period. Archaeological Dialogues 17(1): 65-92.

Warnier J.P. 2006. Inside and outside. Surfaces and Containers. In C. Tilley, W. Keane, S. Küchler, M. Rowlands and P. Spyer (eds.), Handbook of Material Culture. SAGE Publications Ltd. London: 186-196.

Welbourn A. 1984. Endo ceramics and power strategies. In D. Miller, C. Tilley (eds.), Ideology, Power and Prehistory. Cambridge University Press. Cambridge: 17-24.

Winterhalder B. 1983. Opportunity-cost foraging models for stationary and mobile predators. The American $\mathrm{Na}$ turalist 122(1): 73-83.

Winterhalder B., Kennett D. J. 2006. Behavioral Ecology and the Transition from Hunting and Gathering to Agriculture. In D. J. Kennett, B. Winterhalder (eds.), Behavioral Ecology and the Transition to Agriculture. University of California Press. Berkeley, Los Angeles London: 1-21.

Wu X., Zhang C., Goldberg P., Cohen D., Pan Y., Arpin T. and Bar-Yosef 0. 2012. Early Pottery at 20,000 Years Ago in Xianrendong Cave, China. Science 336: 1696-1700.

Zhushchikhovskaya I. S. 2005. Prehistoric Pottery-Making of the Russian Far East. British Archaeological Reports IS 1434. Archaeopress. Oxford.

2009. Pottery-Making in Prehistoric Cultures of the Russian Far East. In P. Jordan, M. Zvelebil (eds.), Ceramics before Farming. The Dispersal of Pottery among Prehistoric Eurasian Hunter-Gatherers. Left Coast Press. Walnut Creek: 121-147.

2012. The Most Ancient Ceramics. The Course of Technological Innovation. Anthropology \& Archeology of Eurasia 51(1): 62-78. 